US Army Corps

of Engineers

Waterways Experiment

Station

\title{
RRDF Field Experiment Wave and Current Data Summary, Fort Story, Virginia
}

by Ernest R. Smith, Jimmy E. Fowler

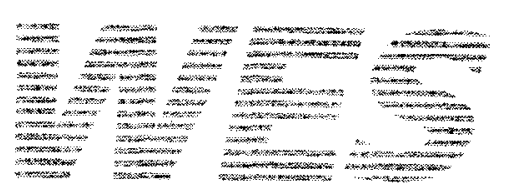

Approved For Public Release; Distribution Is Unlimited 
The contents of this report are not to be used for advertising, publication, or promotional purposes. Citation of trade names does not constitute an official endorsement or approval of the use of such commercial products.

The findings of this report are not to be construed as an official Department of the Army position, unless so designated by other authorized documents. 


\section{RRDF Field Experiment Wave and Current Data Summary, Fort Story, Virginia}

by Ernest R. Smith, Jimmy E. Fowler

U.S. Army Corps of Engineers

Waterways Experiment Station

3909 Halls Ferry Road

Vicksburg, MS 39180-6199

Final report

Approved for public release; distribution is unlimited

Prepared for Transportation Systems Management Office

U.S. Army Tank and Automotive Command

6501 E. 11 Mile Road

Warren, MI 48397-0002 


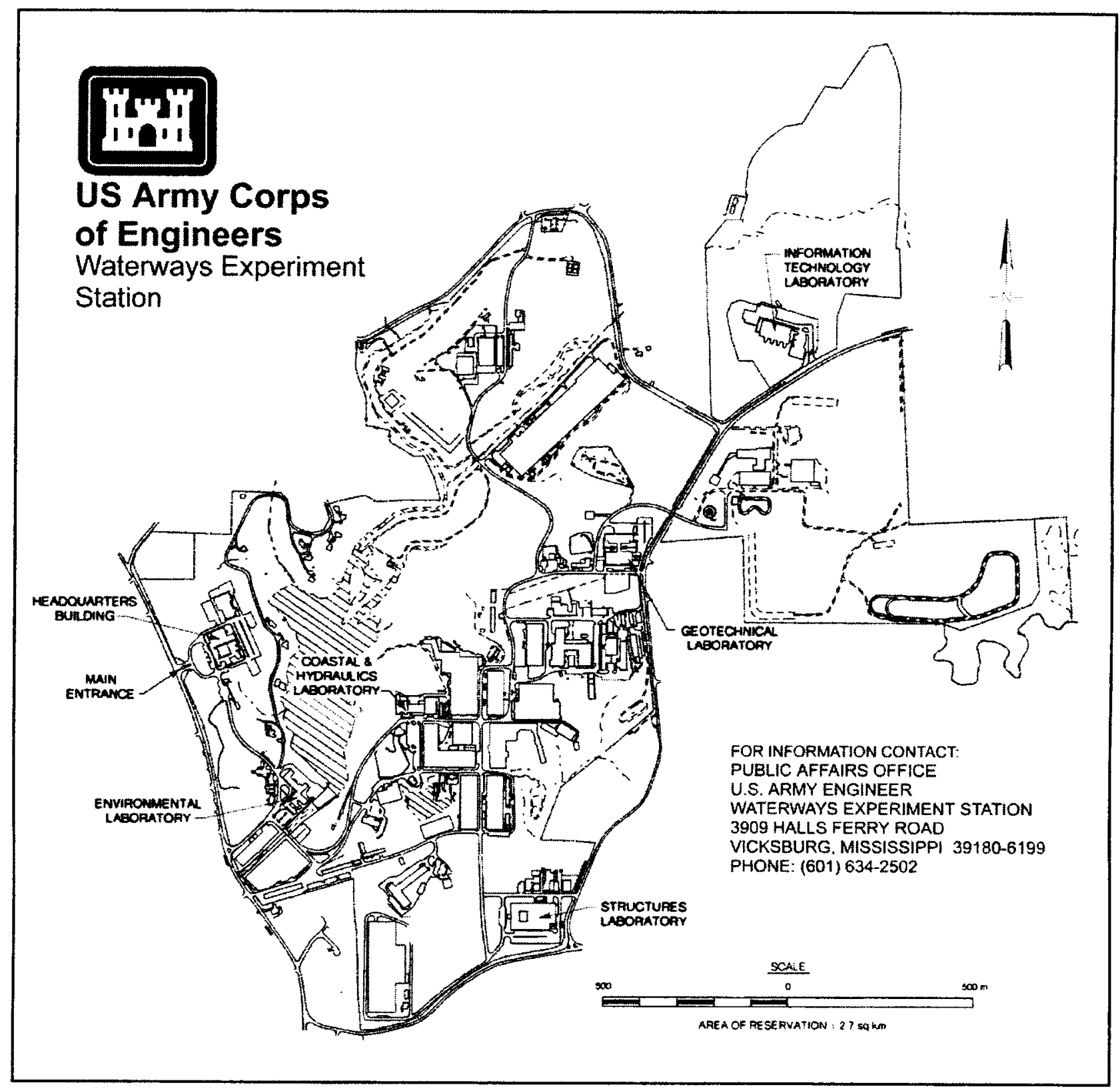

\section{Waterways Experiment Station Cataloging-in-Publication Data}

Smith, Ernest $R$.

RRDF field experiment wave and current data summary, Fort Story, Virginia / by Ernest R. Smith, Jimmy E. Fowler ; prepared for Transportation Systems Management Office, U.S. Army Tank and Automotive Command.

32 p. : ill. ; $28 \mathrm{~cm}$. - (Miscellaneous paper ; CHL-98-8)

Includes bibliographic references.

1. Wind waves - Virginia - Measurement. 2. Water waves - Virginia - Measurement. 3. Ocean waves - Virginia - Measurement. I. Fowler, Jimmy E. II. United States. Army. Corps of Engineers. III. U.S. Army Engineer Waterways Experiment Station. IV. Coastal and Hydraulics Laboratory (U.S. Army Engineer Waterways Experiment Station) V. U.S. Army Tank-Automotive Armaments Command. Transportation Systems Management Office. VI. Title. VII. Series: Miscellaneous paper (U.S. Army Engineer Waterways Experiment Station) ; CHL-98-8.

TA7 W34m no.CHL-98-8 


\section{Contents}

Preface .................... iv

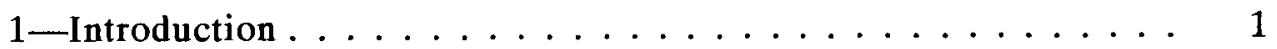

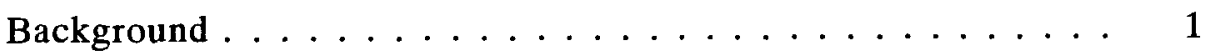

Purpose of Field Experiment . . . . . . . . . . . 3

Purpose of Report . . . . . . . . . . . . . 7

2 -Description of Instrumentation ............ 8

Directional Wave Buoy . . . . . . . . . . . . . . 8

Data Obtained by the ADCP . . . . . . . . . . . 11

3 -Results ...................... 12

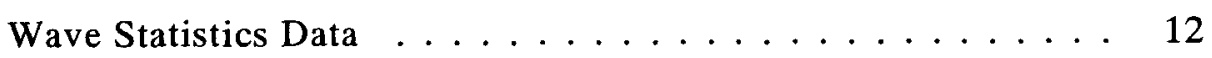

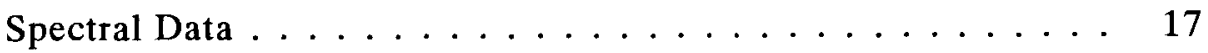

Argos Data .............................. 17

ADCP Data .......................... 22

$4-$ Summary .............................. 27

SF 298 


\section{Preface}

This study was authorized by the Deputy Chief of Staff, Logistics, Headquarters, U.S. Army Corps of Engineers, in support of the Roll-On/Roll-Off Discharge Facility Field Experiment. The study was conducted by the U.S. Army Engineer Waterways Experiment Station (WES), Coastal and Hydraulics Laboratory (CHL), between September 1997 and June 1998, and included field measurements of waves and currents and forecasting of waves.

Data analysis and report preparation were done by Mr. Ernest R. Smith, Coastal Structures Branch (CSB), CHL, and Dr. Jimmy Fowler, Harbors and Entrances Branch (HEB), CHL, under the direction of Dr. James R. Houston and Mr. Charles C. Calhoun, Jr., Director and Assistant Director, CHL, respectively; and the direct guidance of Messrs. C. E. Chatham, Jr., Chief of the Navigation and Harbors Division, CHL, D. D. Davidson, Chief, CSB, and Dennis Markle, Chief, HEB. Mr. Michael Tubman, Prototype Measurements and Analysis Branch (PMAB), CHL, prepared field instruments, oversaw deployment and retrieval of the wave buoy and current meter, and assisted with data analysis under the guidance of Mr. William Preslan, Chief, PMAB, and Mr. Thomas Richardson, Chief, Coastal Sediments and Engineering Division, CHL.

Mr. Robert Van Olst of the U.S. Naval Oceanographic Office provided use of a directional spectral wave buoy. The U.S. Naval Amphibious Base, Little Creek, assisted with manpower and provided vessels during deployment and retrieval of the wave buoy and current meter.

At the time of publication of this report, Director of WES was Dr. Robert W. Whalin. Commander was COL Robin R. Cababa, EN.

The contents of this report are not to be used for advertising, publication, or promotional purposes. Citation of trade names does not constitute an official endorsement or approval of the use of such commercial products. 


\section{Introduction}

\section{Background}

Force projection on a global scale requires the ability to move large quantities of personnel, equipment, and supplies, predominantly via sealift capabilities. In fact, during typical operations, waterborne logistics delivers 90 percent of all unit equipment and supplies in support of U.S. forces. The Desert Storm/Desert Shield and Provide Hope Operations are recent (wartime and peacetime) examples of U.S. military requirements to deploy and sustain forces in support of defense and national security strategies. When suitable port facilities are not available, sustainment efforts must include Logistics Over The Shore (LOTS) operations. Generally, this involves offloading military ships such as roll-on/roll-off (RO/RO) ships, auxiliary crane ships, containerships, and large tankers at

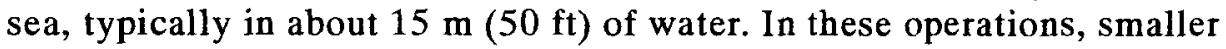
watercraft known as lighters are used to ferry cargo, equipment, and supplies to various offload points at the shore.

A critical component of LOTS operations, specifically those involving $\mathrm{RO} / \mathrm{RO}$ vessels, is the roll-on/roll-off discharge facility (RRDF). The RRDF is assembled from standard modular causeway sections (MCS) and provides the interface between $\mathrm{RO} / \mathrm{RO}$ vessels and the lighters that transport rolling stock to shore. It is essentially a floating platform, which enables vehicles to be driven down the ship's ramp, onto the platform, and then onto lighterage. Generally, the RRDF is assembled by numerous pin connections along the sides as shown in Figure 1 to form semi-rigid sections. These platforms are then joined at the ends to configure the RRDF. A common configuration used for the RRDF during LOTS operations is shown in Figure 2. The Army wishes to increase throughput capacity of the RRDF and improve safety conditions by configuring a considerably larger RRDF as shown in Figure 3. In recent exercises, RRDFs have functioned quite well in relatively calm water, but during more energetic conditions, excessive platform motions in response to incident waves have severely limited or shut down RRDF operations. During energetic seas, excessive motion and water coming over the deck create safety hazards for stevedores as well as vehicle operators. In addition, concern has been expressed over the durability and capacity of the pins in elevated sea states. 


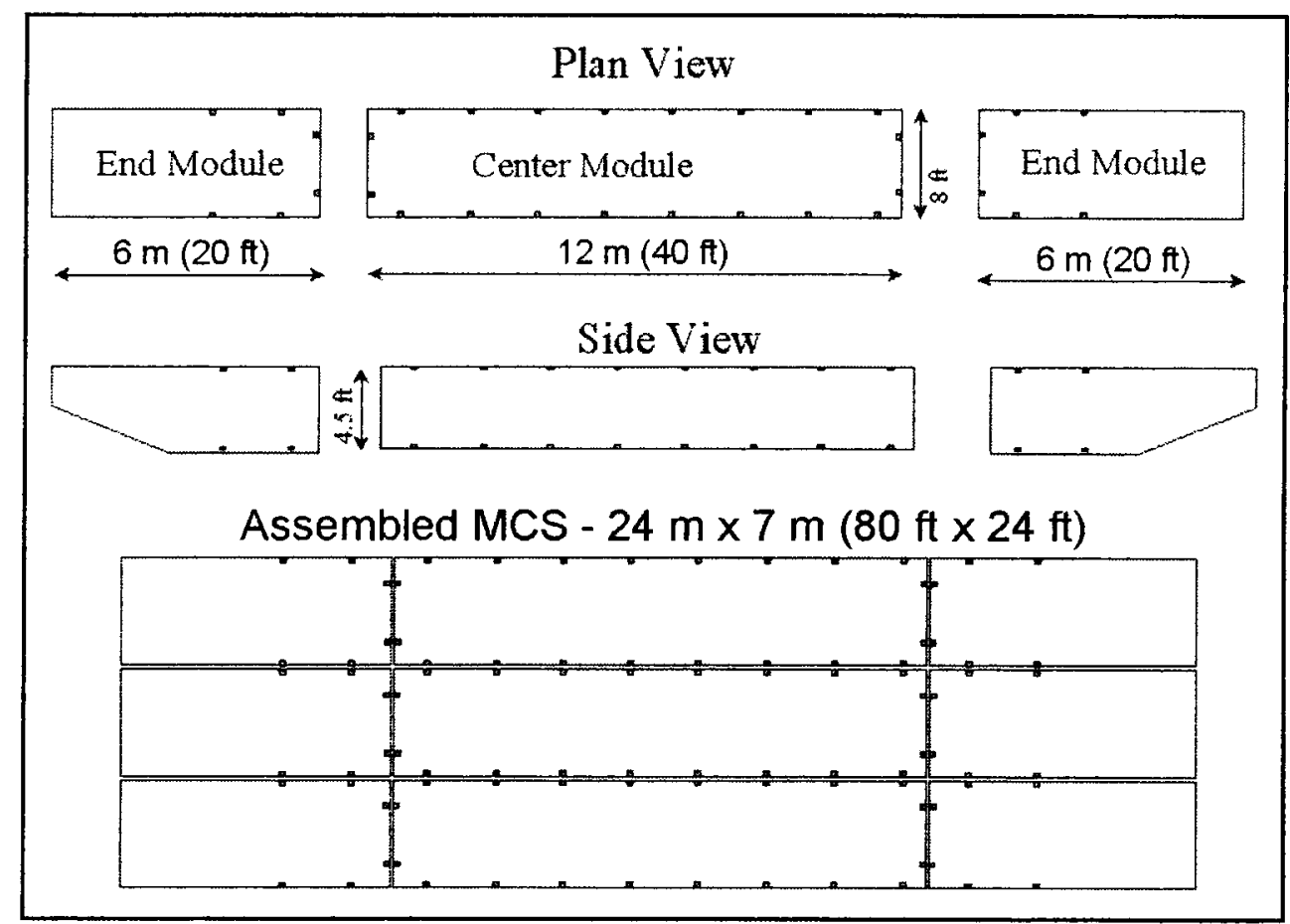

Figure 1. Pin connections used in MCS assembly

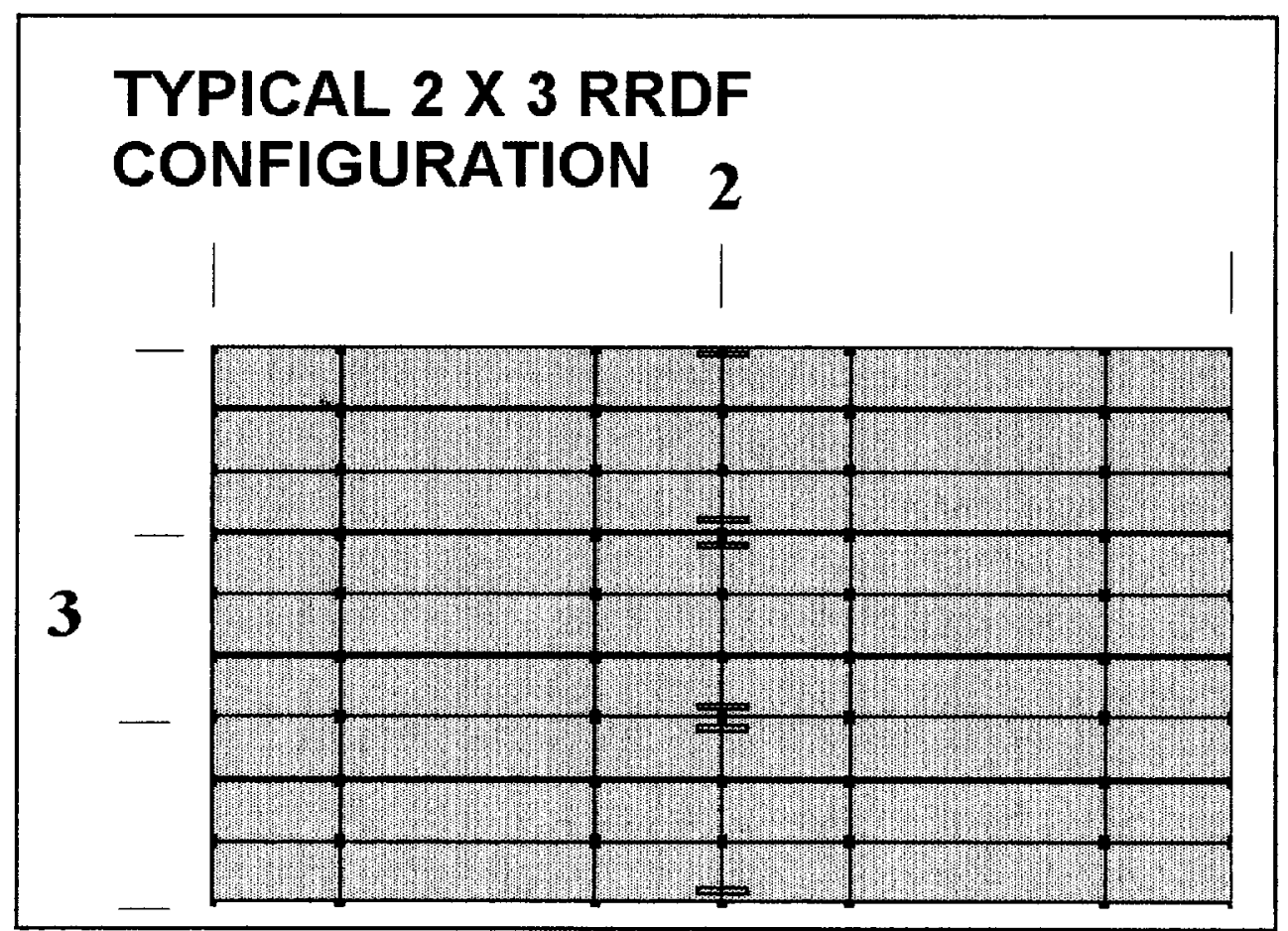

Figure 2. Typical $2 \times 3$ configuration used with RRDF operations 


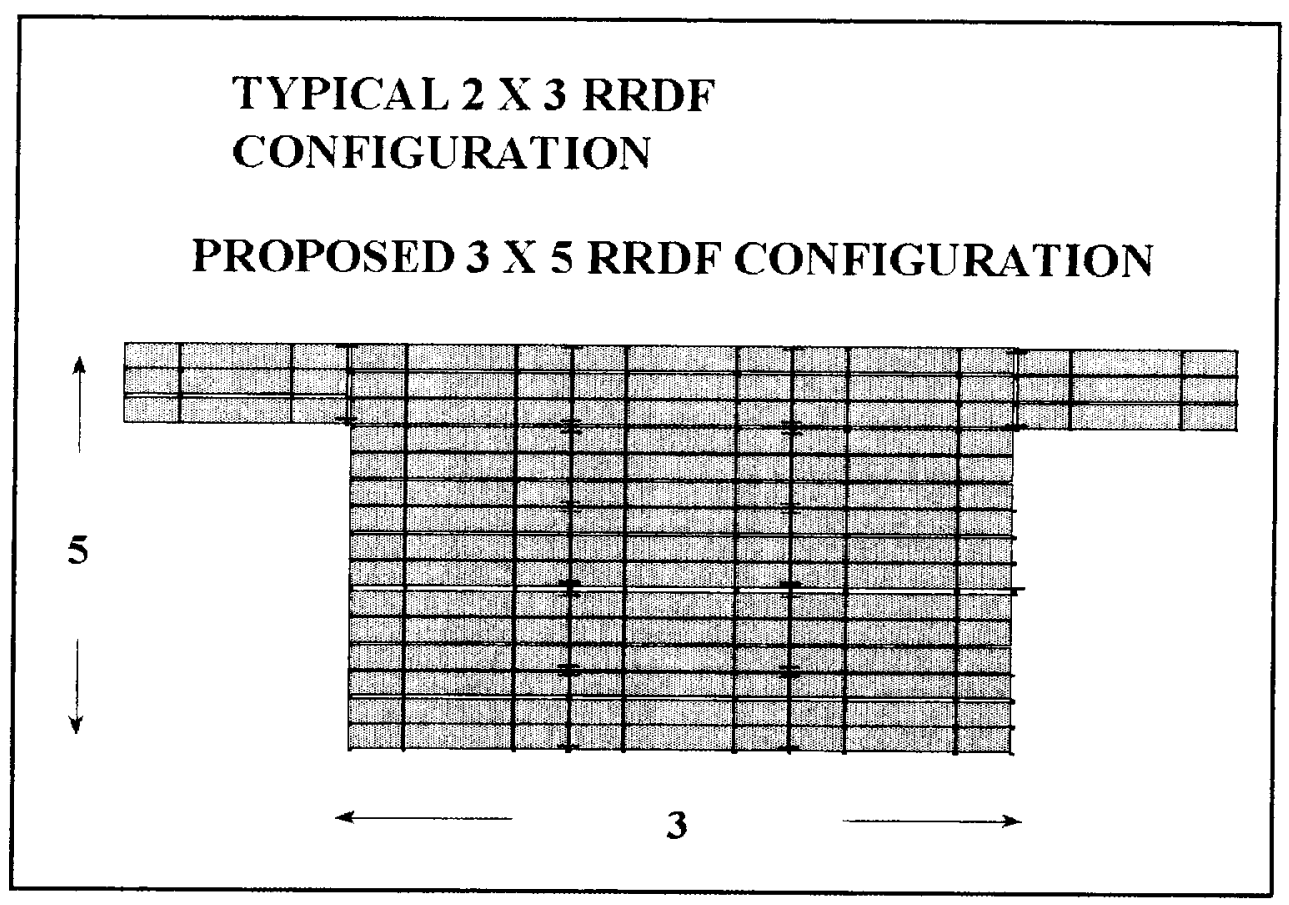

Figure 3. $3 \times 5$ RRDF configuration used for present experiment

\section{Purpose of Field Experiment}

The purpose of the present study was to determine RRDF limitations and operational capabilities in various sea states when configured as shown in Figure 3. The experiment was designed to simulate an RRDF platform loaded to simulate a worst case scenario, which would include the weights of two M1A1 tanks, the RO/RO ramp, and lighterage ramps. The total weight placed on the platform (including instrumentation) was approximately 163 tonnes (180 tons). MCS systems were originally designed for normal operational capability in and through sea state (SS) 2 (significant wave height, $H_{s}$, up to $1 \mathrm{~m}(3.0 \mathrm{ft})$ ) and survivable through SS5 ( $H_{s}$ up to $3.7 \mathrm{~m}(12 \mathrm{ft})$, Table 1$)$. The objective of this effort was to collect structural load data during sea states up to and including SS5.

To obtain wave-induced loads, the platform was instrumented by the U.S. Army Aberdeen Test Center (ATC) with numerous strain gauges and load cells mounted in its internal structure and its module-to-module pin connectors. Other instrumentation installed by ATC included Global Positioning Systems to determine orientation and location of the platform and an anemometer to obtain wind speed and direction. All data collected by the ATC were their responsibility and will be reported in a separate report.

The test site selected for the study was in the Chesapeake Bay, near Fort Story, Virginia (Figure 4). A key factor for site selection was the probability of exposure to wave conditions that would satisfy the 


\begin{tabular}{|c|c|c|c|c|}
\hline Sea State & $\begin{array}{l}\text { Significant Wave } \\
\text { Height, } m \text { (ft) }\end{array}$ & $\begin{array}{l}\text { Significant } \\
\text { Range of } \\
\text { Periods (sec) }\end{array}$ & $\begin{array}{l}\text { Period of } \\
\text { Maximum } \\
\text { Energy (sec) }\end{array}$ & $\begin{array}{l}\text { Average Period } \\
\text { (sec) }\end{array}$ \\
\hline 0 & $0.03(0.10)$ & $0.34-1.09$ & 0.87 & 0.62 \\
\hline 0 & $0.05(0.15)$ & $0.42-1.33$ & 1.07 & 0.76 \\
\hline 1 & $0.15(0.50)$ & $0.77-2.43$ & 1.95 & 1.39 \\
\hline 1 & $0.30(1.00)$ & $1.09-3.43$ & 2.75 & 1.96 \\
\hline 1 & $0.37(1.20)$ & $1.19-3.76$ & 3.02 & 2.15 \\
\hline 2 & $0.46(1.50)$ & $1.34-4.21$ & 3.38 & 2.40 \\
\hline 2 & $0.61(2.00)$ & $1.54-4.86$ & 3.90 & 2.77 \\
\hline 2 & $0.76(2.50)$ & $1.72-5.43$ & 4.36 & 3.10 \\
\hline 2 & $0.91(3.00)$ & $1.89-5.95$ & 4.78 & 3.40 \\
\hline 3 & $1.1(3.50)$ & $2.04-6.43$ & 5.16 & 3.67 \\
\hline 3 & $1.2(4.00)$ & $2.18-6.87$ & 5.52 & 3.92 \\
\hline 3 & $1.4(4.50)$ & $2.31-7.29$ & 5.86 & 4.16 \\
\hline 3 & $1.5(5.00)$ & $2.44-7.68$ & 6.17 & 4.38 \\
\hline 4 & $1.8(6.00)$ & $2.67 \cdot 8.41$ & 6.76 & 4.80 \\
\hline 4 & $2.1(7.00)$ & $2.89-9.09$ & 7.30 & 5.19 \\
\hline 4 & $2.3(7.50)$ & $2.99-9.41$ & 7.56 & 5.37 \\
\hline 5 & $2.4(8.00)$ & $3.08-9.71$ & 7.81 & 5.55 \\
\hline 5 & $2.7(9.00)$ & $3.27-10.30$ & 8.28 & 5.88 \\
\hline 5 & $3.0(10.00)$ & $3.45-10.86$ & 8.73 & 6.20 \\
\hline 5 & $3.7(12.00)$ & $3.78-11.90$ & 9.56 & 6.79 \\
\hline 6 & $4.3(14.00)$ & $4.08-12.85$ & 10.33 & 7.34 \\
\hline 6 & $4.9(16.00)$ & $4.36-13.74$ & 11.04 & 7.84 \\
\hline 6 & $5.5(18.00)$ & $4.63-14.57$ & 11.71 & 8.32 \\
\hline 6 & $6.1(20.00)$ & $4.88-15.36$ & 12.34 & 8.77 \\
\hline 7 & $7.6(25.00)$ & $4.45-17.17$ & 13.80 & 9.80 \\
\hline 7 & $9.1(30.00)$ & $5.97-18.81$ & 15.12 & 10.74 \\
\hline 7 & $10.7(35.00)$ & $5.45-20.32$ & 16.33 & 11.60 \\
\hline 7 & $12.2(40.00)$ & $6.90-21.72$ & 17.46 & 12.40 \\
\hline 8 & $13.7(45.00)$ & $7.32-23.04$ & 18.52 & 13.15 \\
\hline 8 & $15.2(50.00)$ & $7.71-24.28$ & 19.52 & 13.87 \\
\hline 8 & $16.8(55.00)$ & $8.09-25.47$ & 20.47 & 14.54 \\
\hline 8 & $18.3(60.00)$ & $8.45-26.60$ & 21.38 & 15.19 \\
\hline 9 & $21.3(70.00)$ & $9.12-28.73$ & 23.09 & 16.41 \\
\hline 9 & $24.4(80.00)$ & $9.75-30.72$ & 24.69 & 17.54 \\
\hline 9 & $27.4(90.00)$ & $10.35-32.68$ & 26.19 & 18.60 \\
\hline 9 & $30.5(100.00)$ & $10.91-34.34$ & 27.60 & 19.61 \\
\hline
\end{tabular}




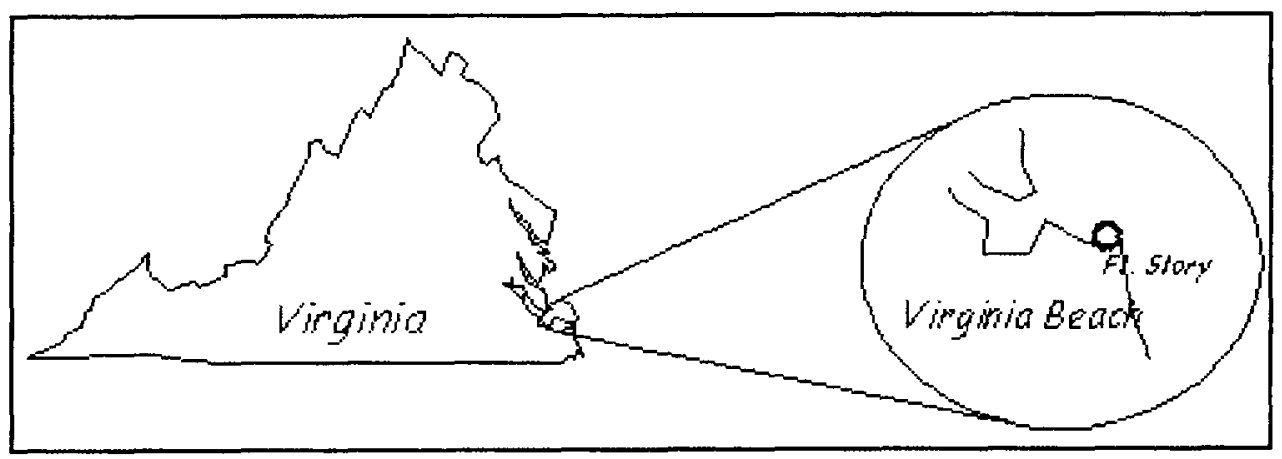

Figure 4. Location of study

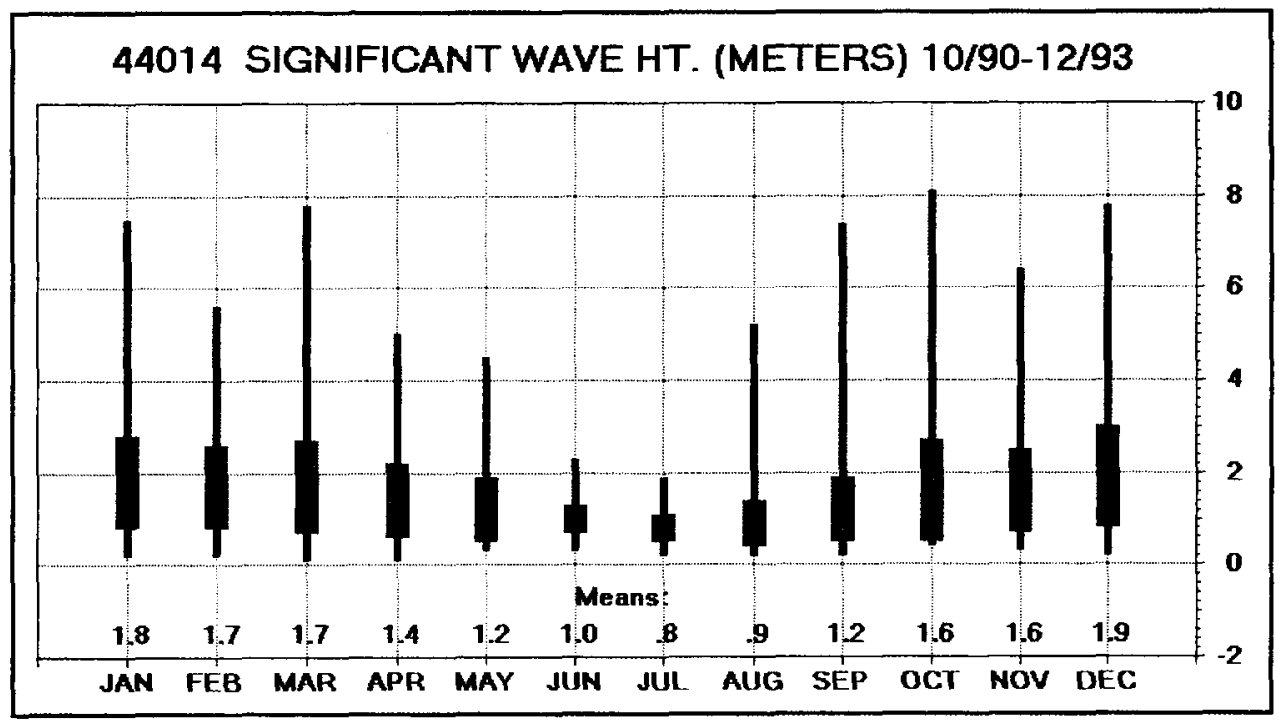

Figure 5. Typical wave climate for test area from National Data Buoy Center

experiment goals. Figure 5 shows the range of significant wave heights recorded by a National Data Buoy Center wave gauge near the test site between 1990 and 1993. The figure indicates that SS2 and SS3 conditions are fairly common during the spring, and that conditions in excess of SS3 are less common, but possible.

Another factor in the site selection was proximity to a safe haven in the event of extreme wave conditions. A heavy weather contingency plan was developed to tow the platform to safety if it appeared that wave conditions would cause damage to the RRDF, instrumentation, or cause the RRDF mooring to fail. A failure in the mooring system could have proven catastrophic, due to the large number of commercial vessels and other structures which could have been damaged by free-floating segments of the RRDF. As part of the contingency plan, the U.S. Army Engineer Waterways Experiment Station (WES), Coastal and Hydraulics Laboratory (CHL), provided sea state forecasts through a contract with Oceanweather Inc., of Cos Cob, Greenwich, Connecticut. The forecasts 
provided expected winds, significant wave height, and peak period for the present day forward in time for the ensuing $96 \mathrm{hr}$. Figure 6 is an example of typical information provided with these forecasts. Forecasts were received at WES via electronic mail, interpreted, edited for clarification, and forwarded to key experiment participants. In order to fine-tune the sea state forecasts, WES deployed a directional wave gauge at the experiment site 2 weeks prior to the actual beginning of the experiment. Forecasted conditions were then compared to actual measured conditions and subsequent adjustments were incorporated into the wave prediction models to improve forecasting accuracy. In addition to the above, $\mathrm{CHL}$ also performed a physical model study to estimate maximum anticipated

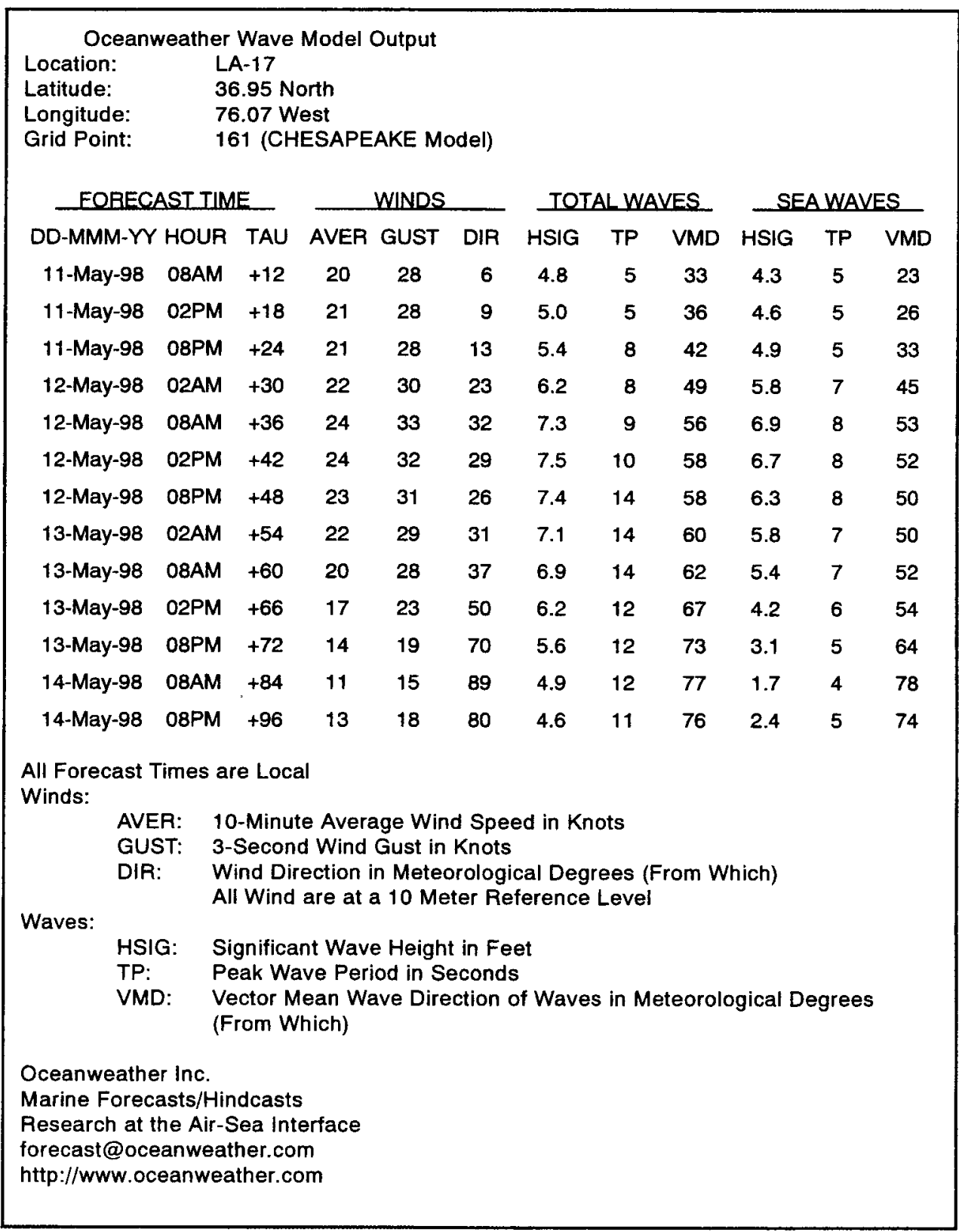

Figure 6. Typical information provided in daily forecasts 
mooring loads on the structure and to determine adequacy of the mooring buoy selected for use in the study.

Soldiers from the 331st Transportation Company (MCS) (a component of the 11th Transportation Battalion, 7th Transportation Group) assembled the RRDF platform in the Third Port facilities at Fort Eustis, Virginia, and then towed the platform to the test site on 29 April 1998. Strain gauge data collection began on 9 May 1998 after final installation and calibration of instruments were completed. Environmental and strain/load gauge data were collected daily every $4 \mathrm{hr}$ until the RRDF was removed on 9 June 1998.

\section{Purpose of Report}

In addition to wave forecasting, CHL was responsible for collecting wave and current data in the vicinity of the RRDF. The purpose of this report is to document the wave and current data collected during the field experiment. Descriptions of the instruments used to collect wave and current information and the type of information obtained are located in Chapter 2. Sample data are plotted in Chapter 3 and the wave and current portion of the field experiment is summarized in Chapter 4 . A more complete description and discussion of the overall field experiment will be available in the comprehensive report to be published by the Tank and Automotive Command. 


\section{Description of Instrumentation}

To obtain the data required to document sea state and allow subsequent RRDF analysis for the study, a directional wave buoy and an acoustic Doppler current profiler (ADCP) were deployed. The wave buoy provided wave height, period, and direction, and the current meter recorded speed and direction of water currents at various depths throughout the water column. This chapter describes the instruments used and the type of data obtained from each.

The wave buoy and ADCP were deployed and retrieved with the assistance of Navy personnel from Beach Group 2 and Seal Team 4, both from the Little Creek Naval Amphibious Base. A specialized vessel known as a Side-Loadable Warping Tug (SLWT) was used for each of these operations. The SLWT features a large, flat working platform and an on-board A-frame with winch that was used to deploy and retrieve the equipment. The wave buoy and current meter were located as shown in Figure 7.

\section{Directional Wave Buoy}

The main feature of the directional wave buoy used for the study was a 0.9-m-diam stainless steel sphere. The buoy contained a heave-pitch-roll sensor, compass, two fixed $x$ and $y$ accelerometers, a temperature sensor, and a micro-processor. Real-time data collection was achieved by transmission of data to a receiver located approximately 2 miles $(3.7 \mathrm{~km})$ from the wave buoy. Information obtained from the buoy measurements included statistical wave heights, periods, and direction. Peak or maximum values for key wave parameters such as height and period were also recorded.

The buoy was moored at the study site from 29 April 1998 through 16 June 1998 at a latitude of $36 \mathrm{deg} 56.790 \mathrm{~min} \mathrm{~N}$ and a longitude of $76 \mathrm{deg} 14.847 \mathrm{~min}$ W, approximately $600 \mathrm{~m}$ southwest of the Navy mooring buoy designated as LA 17 . Although the wave buoy was located 


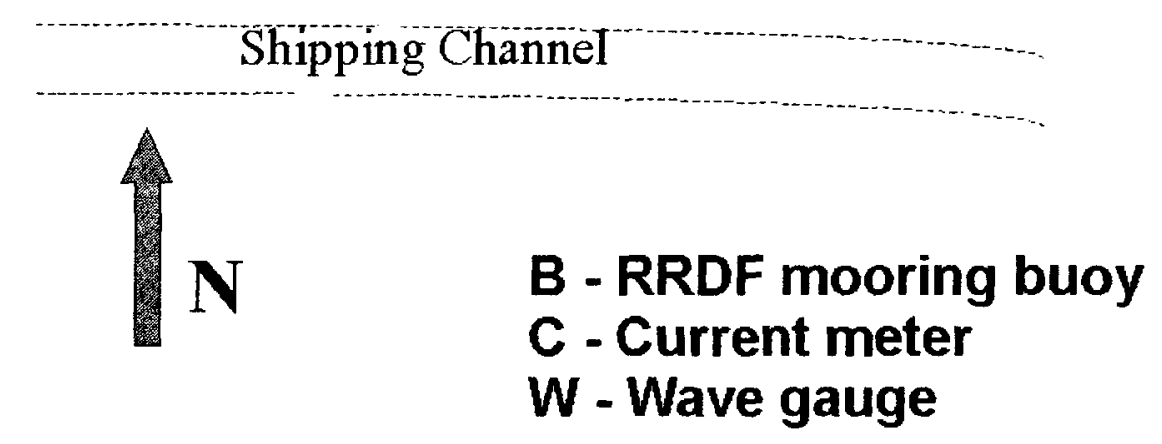

Ebb tide orientation

Flood tide orientation

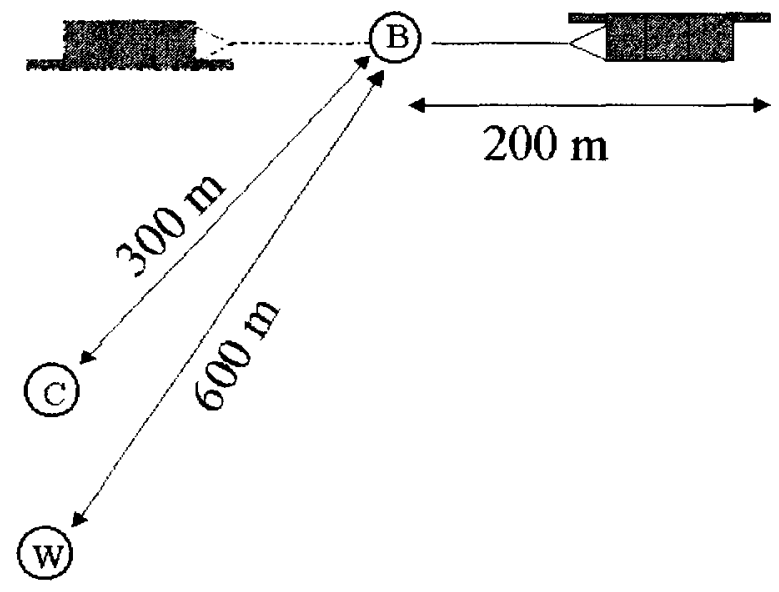

Figure 7. Schematic showing relative locations of RRDF, wave buoy, mooring buoy, and acoustic Doppler current meter

several hundred meters from the RRDF, the bathymetry of the study site is relatively flat (water depths of about $9 \mathrm{~m}$ ) and it could be inferred that wave heights measured at the buoy would be consistent with those at the RRDF platform for nonbreaking waves.

Measured data were transmitted from the buoy to a receiver located at the data collection and processing center established by Aberdeen Test Center at the Virginia Beach Hotel. A computer was programmed to collect data for 20 min once per hour at a sampling rate of $1.28 \mathrm{~Hz}$, unless $H_{s}$ reached $1 \mathrm{~m}$, at which time data were collected twice per hour at the same rate. Occasionally it was necessary to perform a data backup by downloading data files to disks. This process required a temporary suspension of data collection until the backup was completed. Three data files were saved for each collection period; a raw data file, a wave statistics file, and 
a directional data file. Additionally, the same transmitted data were received from an Argos satellite at intermittent intervals corresponding to the satellite's rate of orbit.

\section{Raw data}

Four columns of data were written to a file (identified by a RAW extension) for each data collection period. The columns of data represented error status, vertical north, and vertical west displacements, respectively. Error status indicated if any transmission errors occurred during the data sample. Displacements were calculated by the microprocessor from accelerations measured by the buoy. For the given duration and sampling rate of data collection, 1,536 rows of recorded data were written to each raw data file.

\section{Wave statistics}

Wave statistics files (identified by a WAV extension) contained one header line of data as described in Table 2 below. A row of data for each wave of the data series followed the summary line. The individual rows of wave data consisted of four columns: the ordinal pointer, height of the wave crest, height of the wave trough, and wave period.

\section{Table 2}

Wave Statistics Transmitted by the Wave Buoy

\begin{tabular}{|l|l|l|}
\hline Symbol & Name & Definition \\
\hline$H_{\max }$ & Maximum wave height & Largest wave height measured during recording period \\
\hline$T_{\max }$ & Period of $H_{\max }$ & Wave period associated with the maximum wave height \\
\hline$H_{1 / 10}$ & Ten-percent wave height & Average of the highest one tenth of recorded wave heights \\
\hline$T_{1 / 10}$ & Period of $H_{1 / 10}$ & Average period associated with $H_{1 / 10}$ \\
\hline$H_{s}$ & Significant wave height & Average of the highest one third of the wave heights \\
\hline$T_{s}$ & Significant wave period & Average period associated with $H_{s}$ \\
\hline$H_{\text {avg }}$ & Average wave height & Average value of all recorded wave heights \\
\hline$T_{\text {avg }}$ & Average period & Average value of all recorded wave periods \\
\hline$\gamma$ & $\begin{array}{l}\text { Spectral peakedness } \\
\text { parameter }\end{array}$ & $\begin{array}{l}\text { Parameter used to describe energy distribution with a wave } \\
\text { spectrum }\end{array}$ \\
\hline
\end{tabular}

\section{Spectral data}

Spectral data files (identified by an SPT extension) contained summary information for the sampling period and frequency bands used to characterize the spectral parameters. Summary data included: zero-moment wave height $H_{m o}$, average period $T_{a v g}$, maximum spectral density, accelerometer offsets, and compass heading. Data included in each of 
64 frequency bands between 0.025 to $0.58 \mathrm{~Hz}$ included: normalized spectral density, mean direction, directional spread, skewness, and curtosis.

\section{Argos data}

Argos is a satellite-based system which collects, processes, and disseminates a variety of data worldwide. The wave buoy continually transmitted data which were received and retransmitted by the satellite while it was deployed. These transmissions were received when the Argos satellite was within range of the buoy's transmitter. Since the times for data collection from Argos were dependent on satellite position, the Argos data were not obtained on regular hourly intervals. Data analyzed from Argos were $H_{m 0}$, average period, peak period, $T_{p}$, mean direction, and directional spread.

\section{Data Obtained by the ADCP}

An ADCP was deployed on 6 May 1998 and retrieved on 19 June 1998. The ADCP was located at latitude $36 \mathrm{deg} 56.873 \mathrm{~min} \mathrm{~N}$, longitude $76 \mathrm{deg}$ $04.624 \mathrm{~min} \mathrm{~W}$, about $300 \mathrm{~m}$ from the mooring buoy as was shown in Figure 7. During ebb tide cycles, the ADCP was about $200 \mathrm{~m}$ from the RRDF, and during flood tide cycles, the ADCP was about $400 \mathrm{~m}$ from the RRDF. Unlike the wave buoy, which provided data in real-time, the current meter was mounted on the bottom of the bay at a water depth of about $10 \mathrm{~m}$ and was self-recording. The ADCP sensor faced upward (toward the surface) and measured current speed and direction every 20 min at 15 depths, or bins, throughout the water column. The distance between each bin was $0.5 \mathrm{~m}$ and the first (deepest) bin was located $1.75 \mathrm{~m}$ above the bottom and the 15 th (highest) bin was located approximately $9.24 \mathrm{~m}$ above the bottom. The ADCP collects data at $150 \mathrm{kHz}$ and also provides maximum and average values for each of the bins described above. 


\section{Results}

Data collection in conjunction with the RRDF field experiment began on 9 May 1998 and continued to 9 June 1998. The site experienced heavy weather during the first week of data collection. Wave conditions were generally moderate for the remainder of the experiment. This chapter summarizes the wave and current data collected during the experiment.

\section{Wave Statistics Data}

Figures 8 through 13 give a time-history of $H_{\max }$ and $H_{s}$ during the experiment. Figure 8 shows the energetic wave conditions that accompanied a storm during the period 10 May to 13 May. The highest single wave recorded during this storm (and entire duration of measurements) was $2.77 \mathrm{~m}(9.1 \mathrm{ft})$. This wave was recorded at 3:32 a.m. on 13 May 1998 . Additionally, a $2.73-\mathrm{m}(9.0-\mathrm{ft})$ wave occurred at $7: 31$ p.m. on 13 May. Significant wave heights remained above $1 \mathrm{~m}$ between 3:32 p.m. 12 May and 10:32 p.m. 13 May. The maximum $H_{s}$ recorded during the experiment was $1.45 \mathrm{~m}(4.8 \mathrm{ft})$, which translates to an upper SS3 condition.

Wave heights at the test site decreased through 16 May (Figures 8 and 9) to an SS1 condition. Conditions for the remainder of the experiment were typically SS1, $H_{s}$ less than $0.36 \mathrm{~m}(1.2 \mathrm{ft})$ and SS2 $\left(H_{s}\right.$ greater than $0.46 \mathrm{~m}(1.5 \mathrm{ft}) . \mathrm{SS} 2$ was reached on nine occasions following the storm of the first week: 22 May (Figure 9), 23 May (Figure 10), 1 June, 3 through 4 June, and 5 June (Figure 12), 6 June, twice on 7 June, and 8 June (Figure 13).

Figures 14 through 16 show $H_{s}$ and $T_{s}$ as a function of date for the first three weeks of the experiment. Significant period steadily increased from $4.0 \mathrm{sec}$ on 11 May to a peak of $8.5 \mathrm{sec}$ on 15 May (Figure 14). Wave height decreased following 13 May, but period increased through 15 and 16 May (Figures 14 and 15), indicating that swell was reaching the site from the distant storm. Figures 15 and 16 show $T_{s}$ returning to approximately $4.0 \mathrm{sec}$ for the week of 23 through 29 May. 


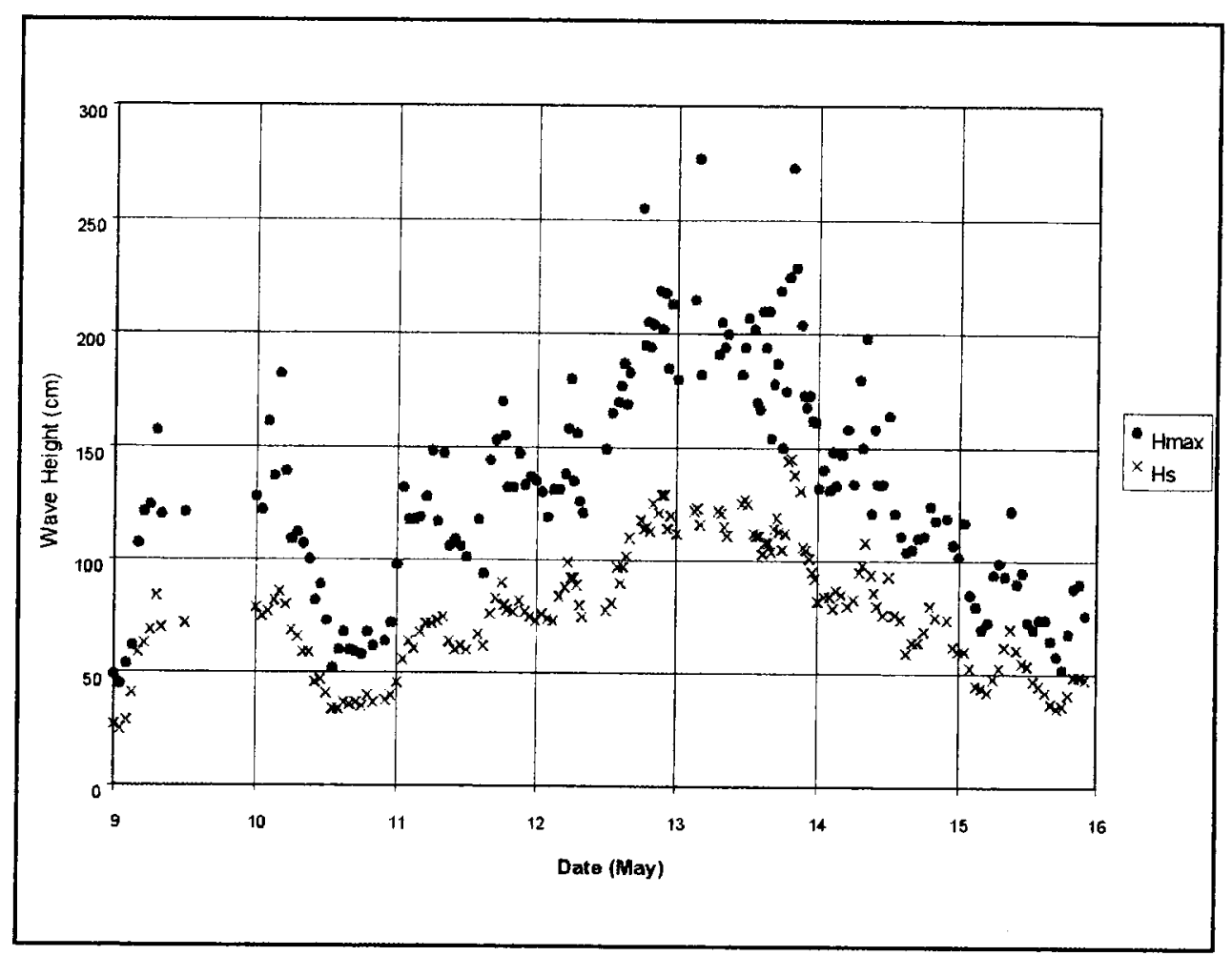

Figure 8. Wave heights from 9 May through 15 May

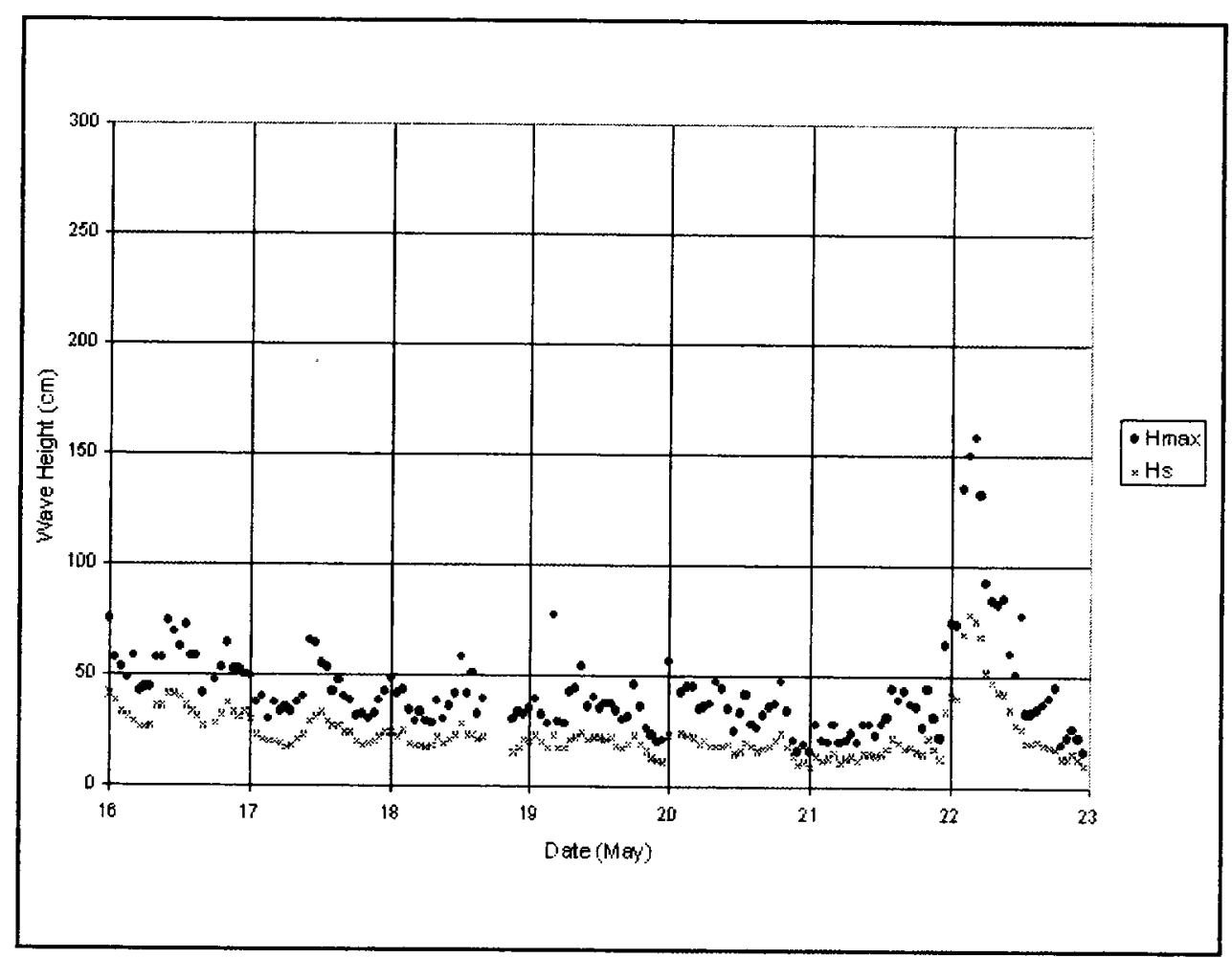

Figure 9. Wave heights from 16 May through 22 May 


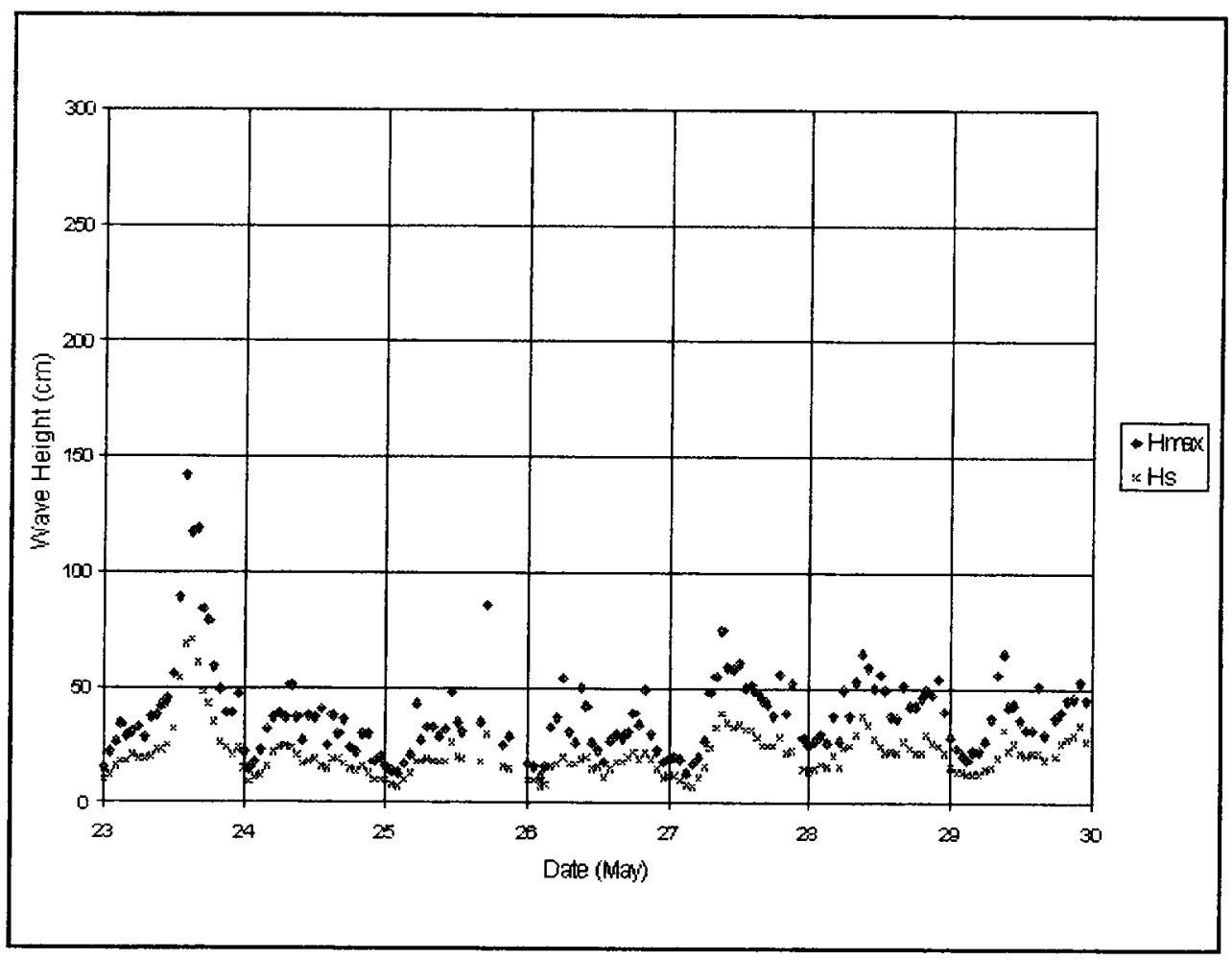

Figure 10. Wave heights from 23 May through 29 May

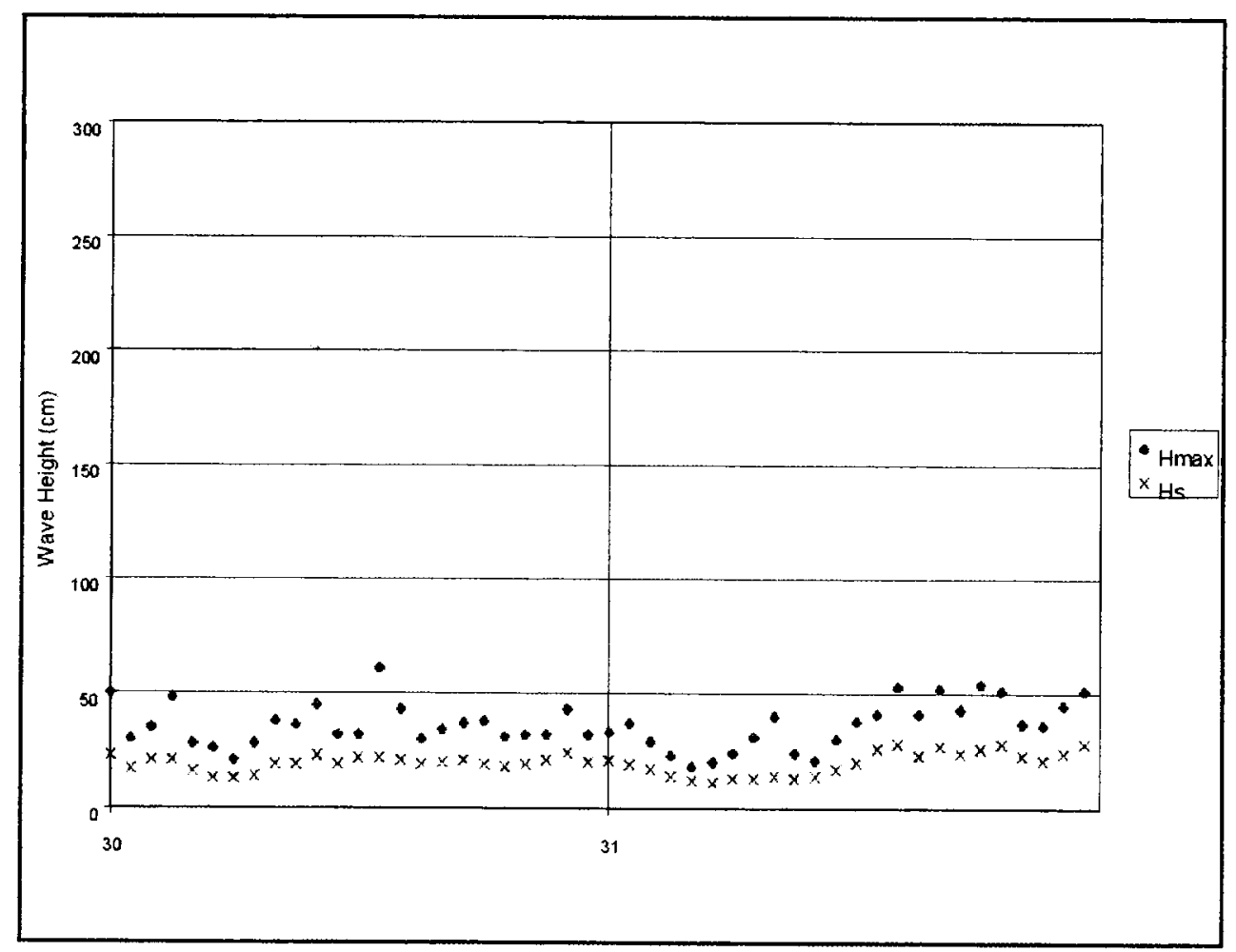

Figure 11. Wave heights from 30 May and 31 May 


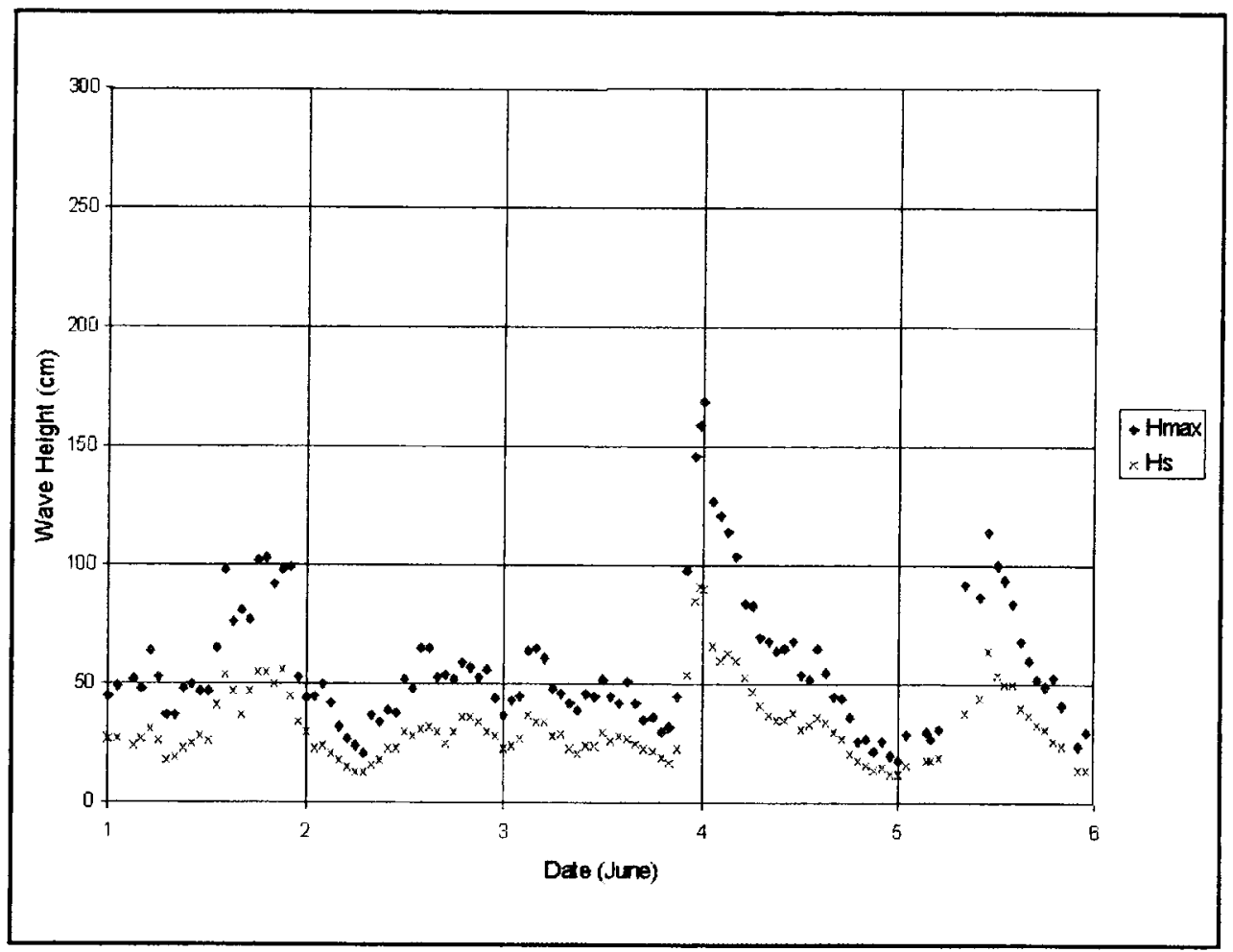

Figure 12. Wave heights from 1 June through 5 June

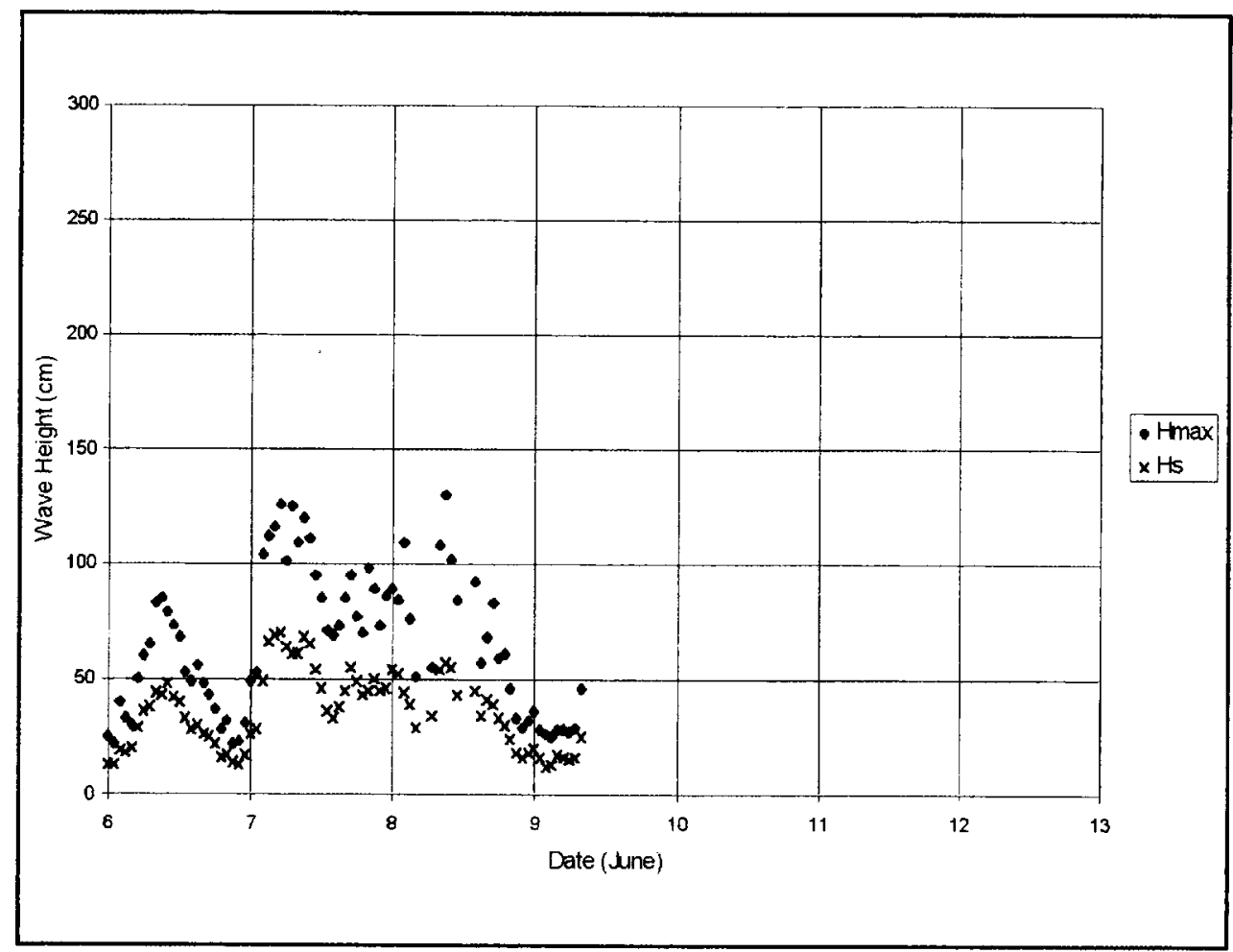

Figure 13. Wave heights from 6 June through 9 June 


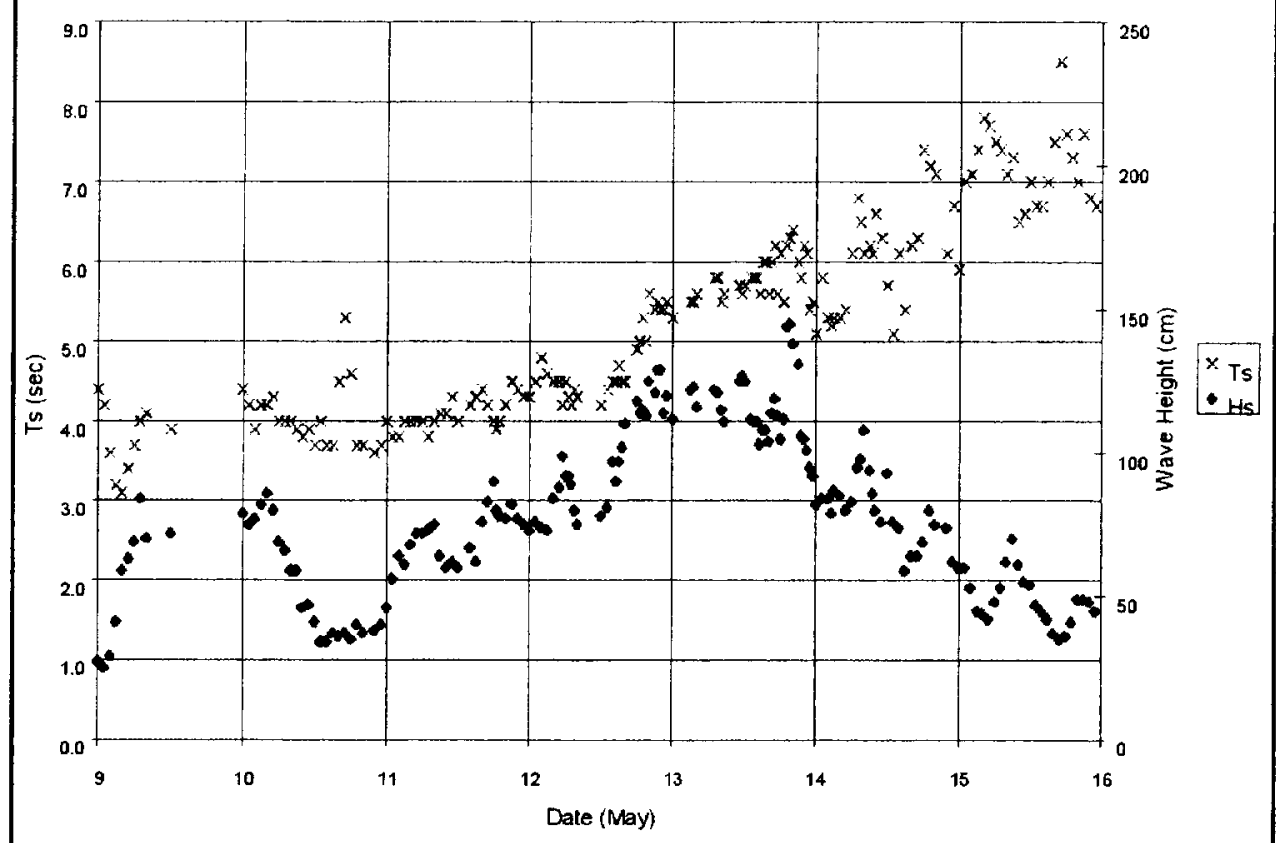

Figure 14. Significant wave height and wave period from 9 May through 15 May

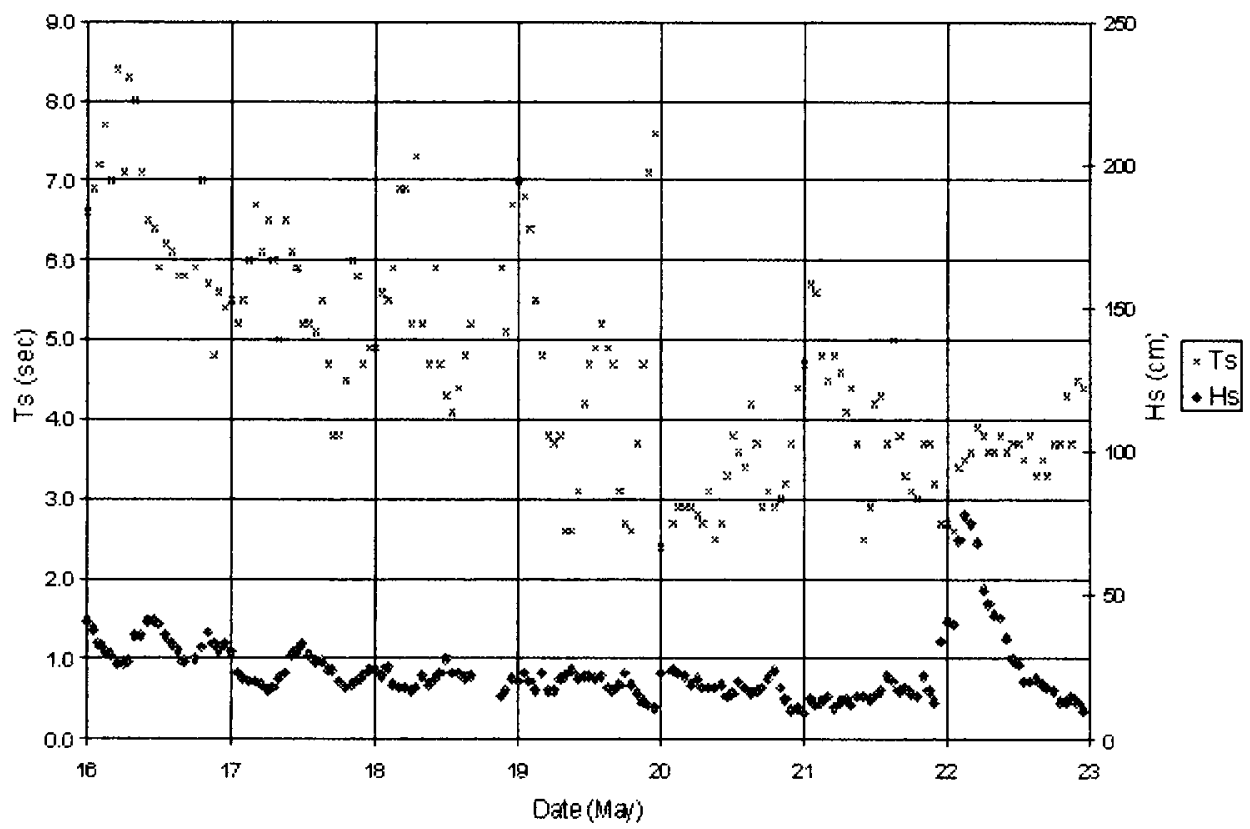

Figure 15. Significant wave height and wave period from 16 through 22 May 


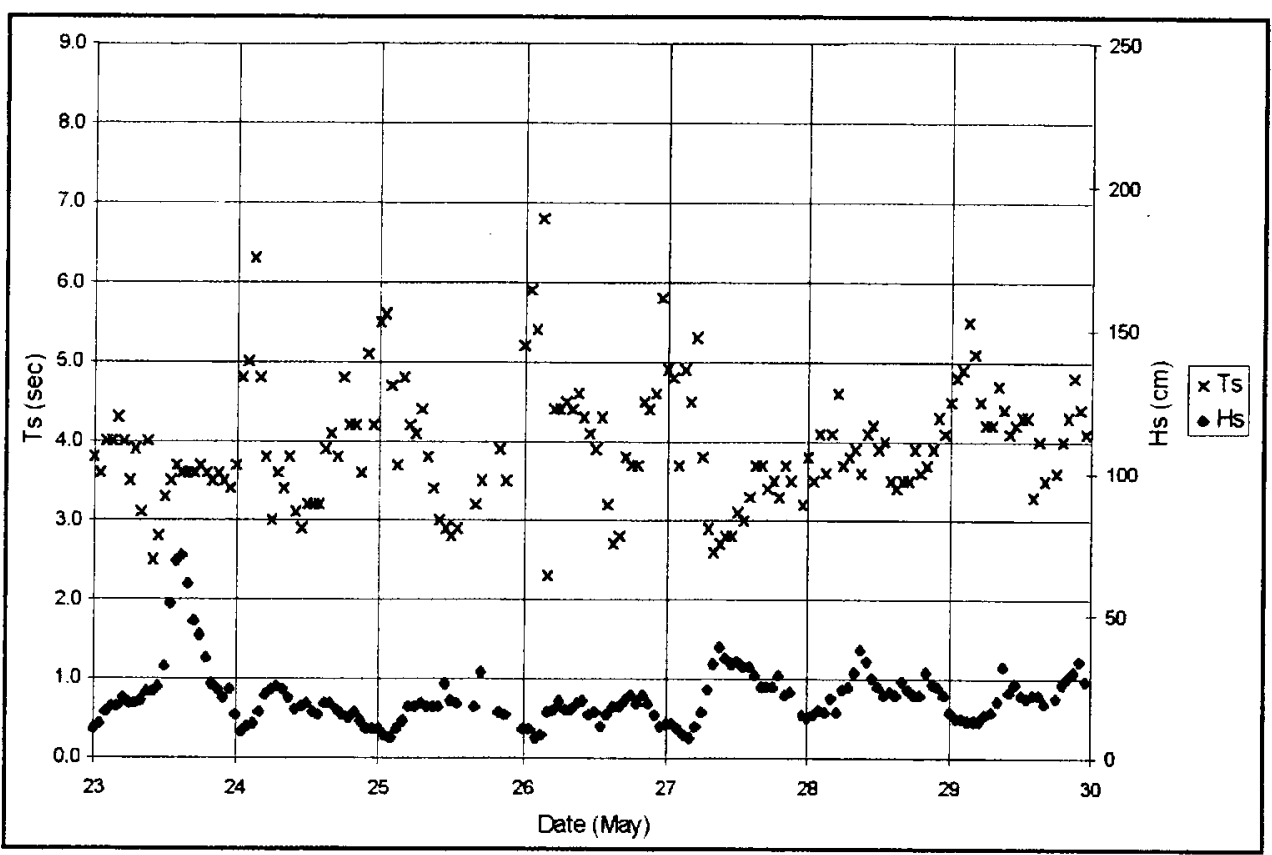

Figure 16. Significant wave height and wave period from 23 through 29 May

\section{Spectral Data}

Figure 17 shows normalized spectral density (energy density measured at a frequency normalized by the maximum energy density of the spectrum) versus frequency for data collected on 13 May at 3:01 a.m. The figure shows multiple peaks, the maximum peak occurs at a frequency of $0.13 \mathrm{~Hz}(7.7 \mathrm{sec})$ and two other peaks located between 0.20 and $0.27 \mathrm{~Hz}$ $(3.7$ to $5.0 \mathrm{sec}$ ). The figure indicates that two wave trains (seas and swell) were present during the storm.

Figure 18 shows directional spectra for the same data series. The figure shows that swell occurred from 90 deg magnetic (easterly) and seas were evident between 45 and $62 \mathrm{deg}$ (east-northeasterly).

\section{Argos Data}

Figures 19 through 24 show $H_{m o}$ as a function of date for the duration of the experiment. Argos data were not received at regular intervals and less data were available. As expected, $H_{m o}$ follows the trend of $H_{\max }$ and $H_{s}$ during the experiment. Maximum $H_{m o}$ was $1.33 \mathrm{~m}(4.4 \mathrm{ft})$ for data collected between 4:00 a.m. and 7:55 a.m., and at 5:31 p.m. and 7:19 p.m. on 13 May (Figure 19). 


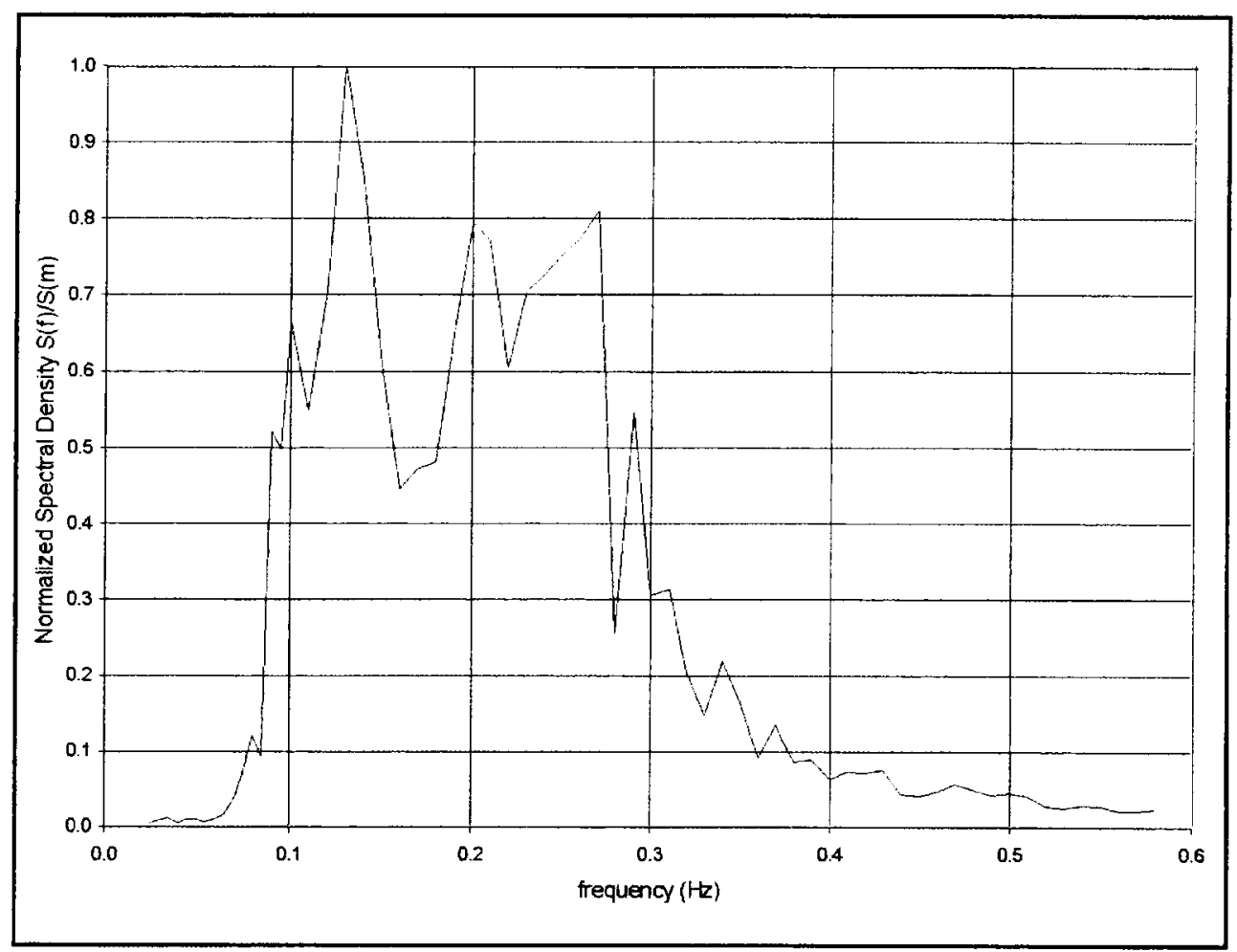

Figure 17. Normalized spectral density versus frequency (13 May, 3:01 a.m.)

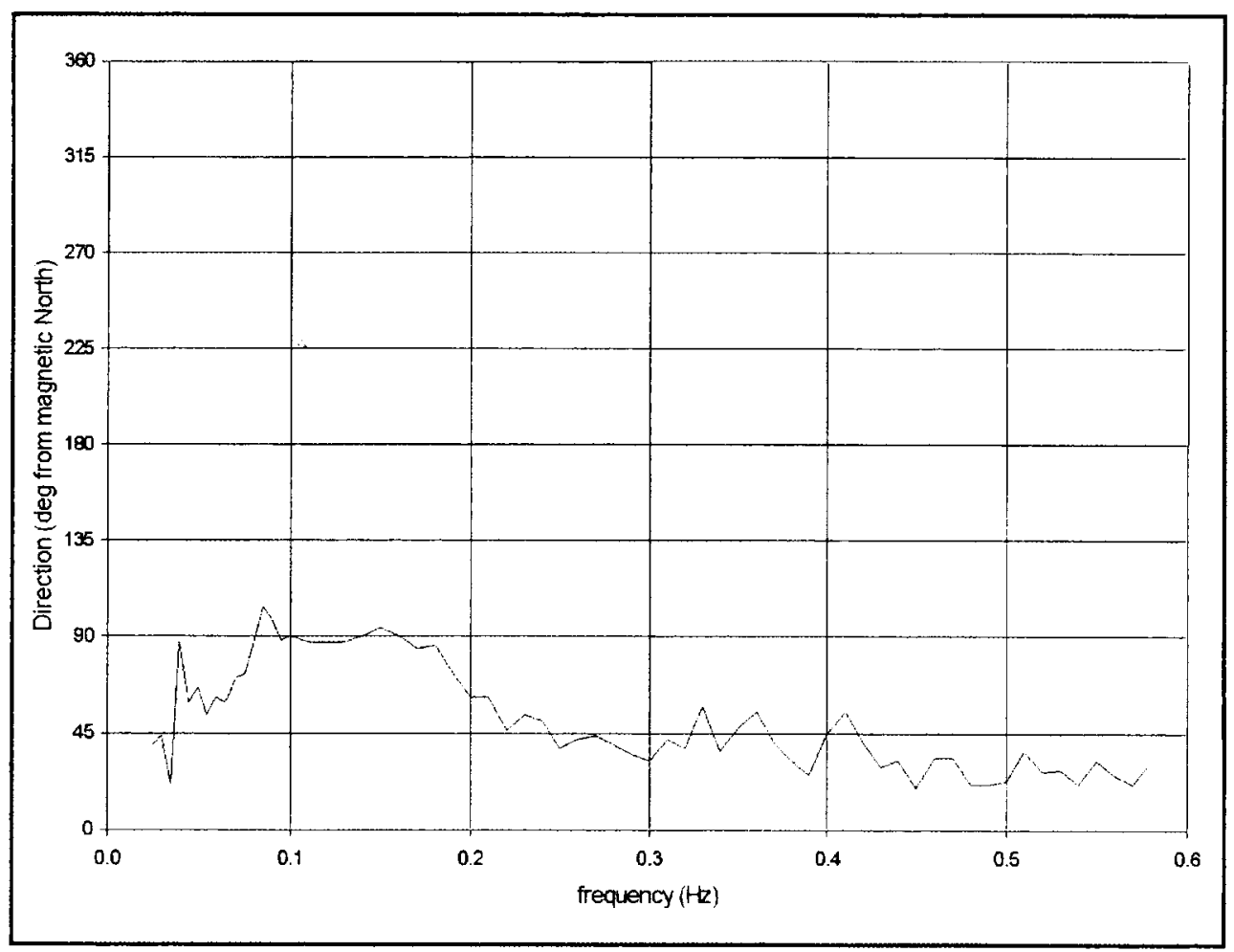

Figure 18. Wave direction versus frequency (13 May, 3:01 a.m.) 


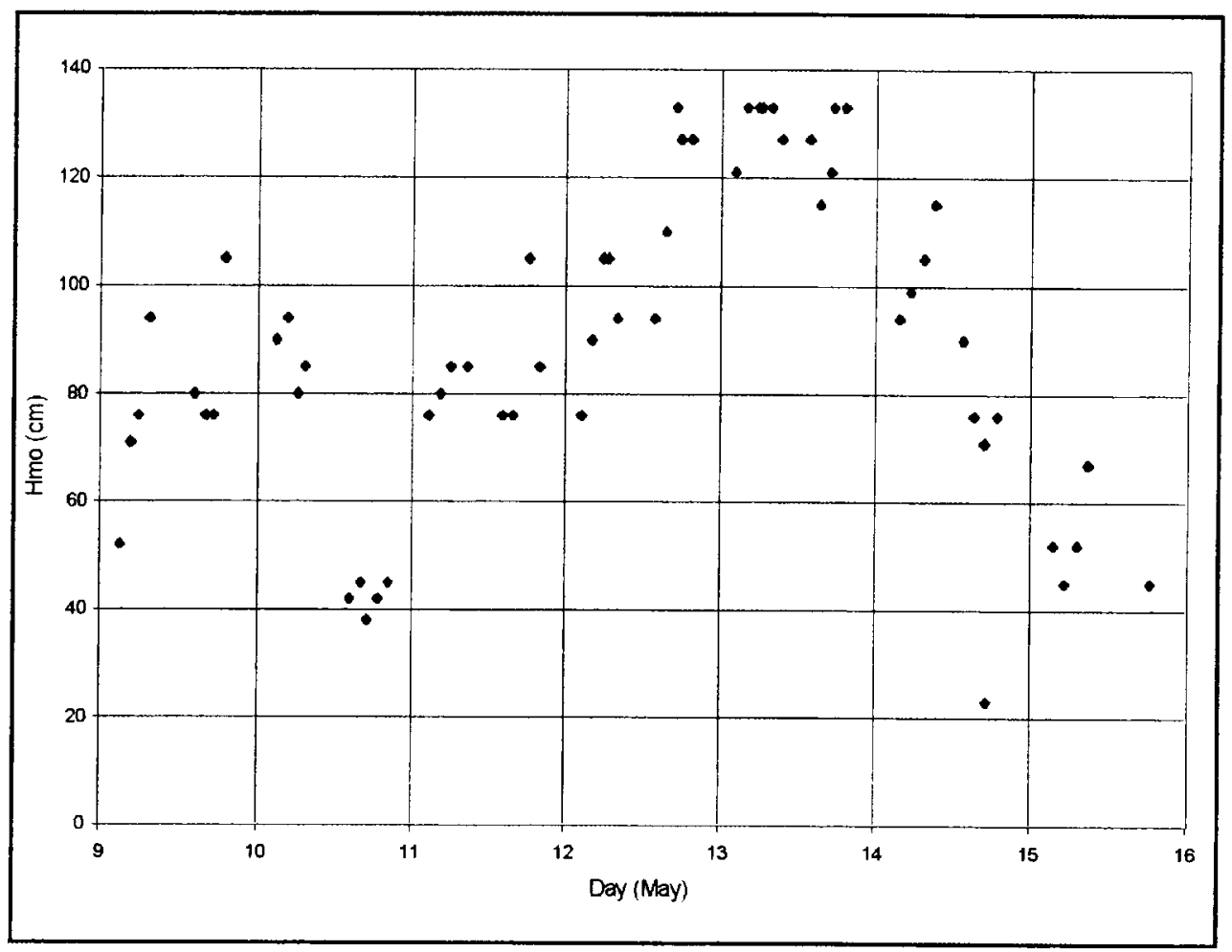

Figure 19. Measured $H_{\text {mo }}$ from 9 May through 15 May

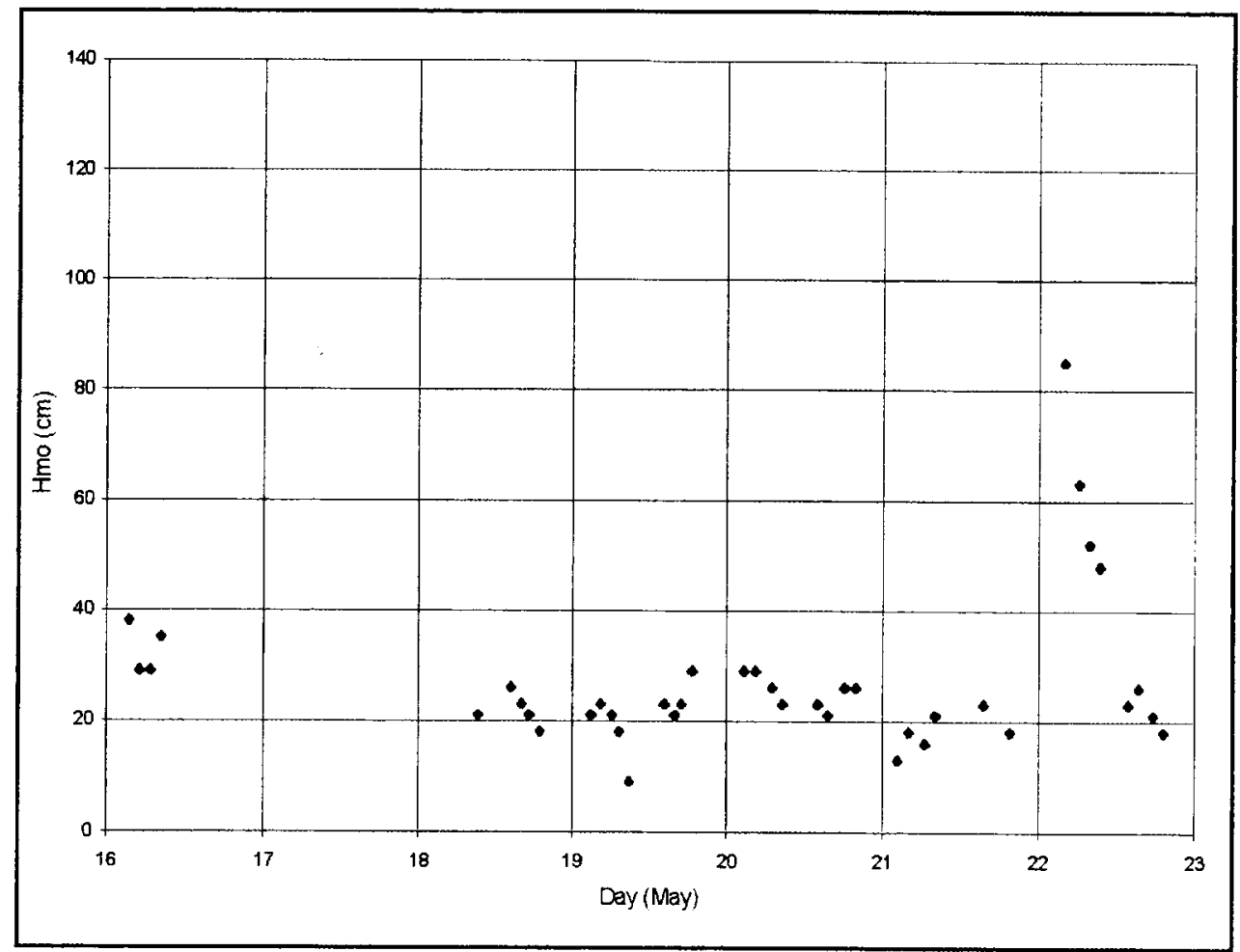

Figure 20. Measured $H_{\text {mo }}$ from 16 May through 22 May 


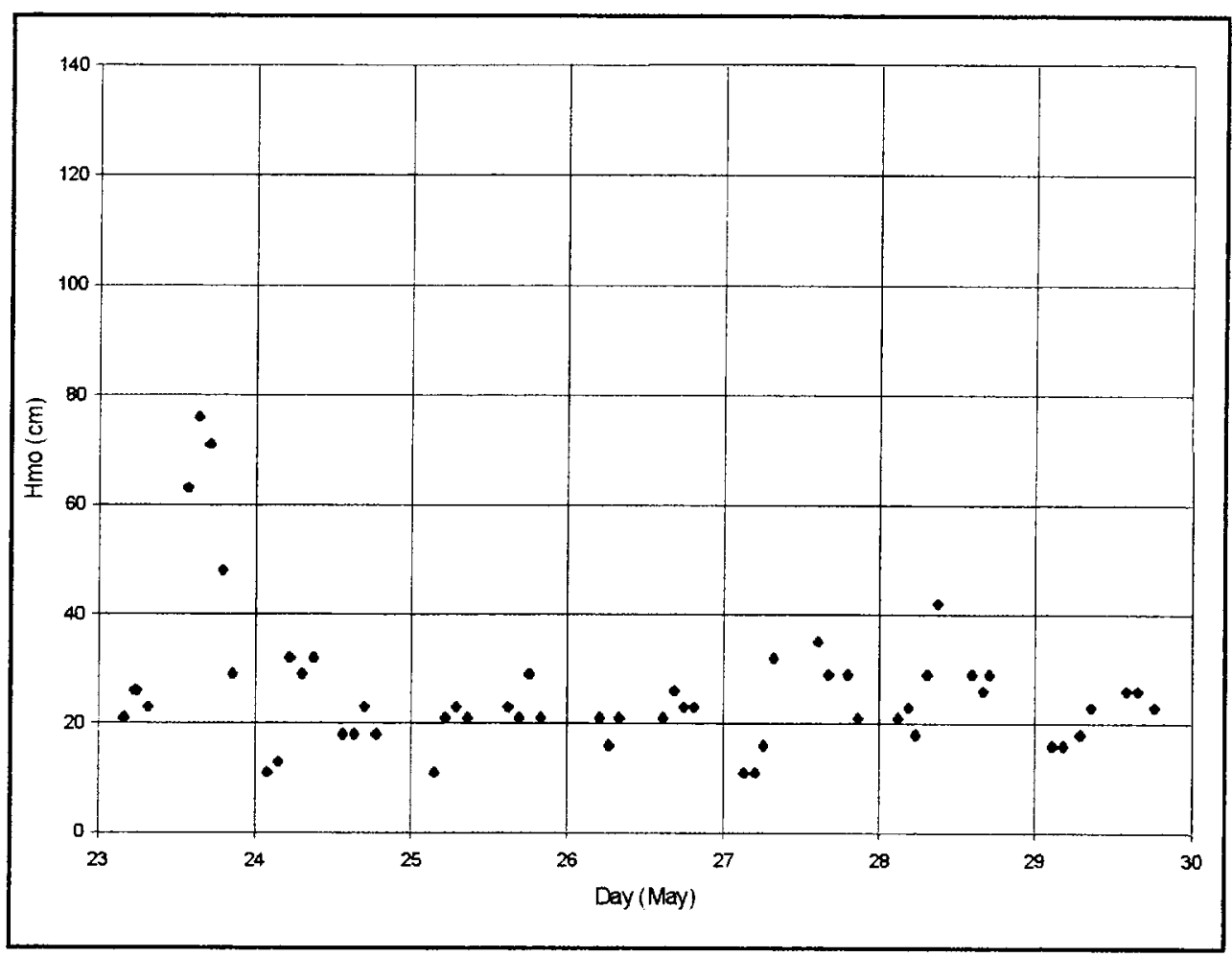

Figure 21. Measured $H_{\text {mo }}$ from 23 May through 29 May

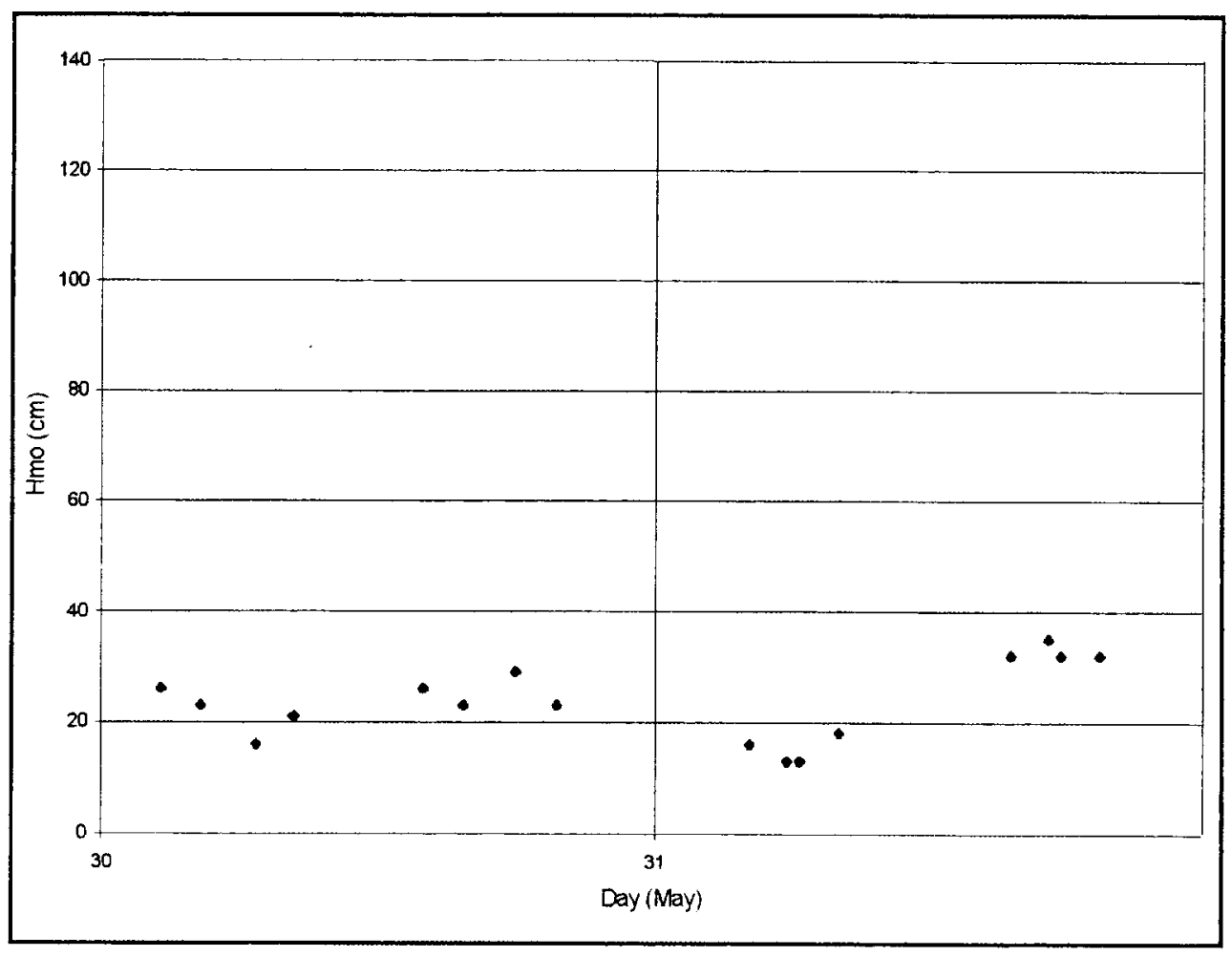

Figure 22. Measured $H_{\text {mo }}$ from 30 May and 31 May

20

Chapter 3 Results 


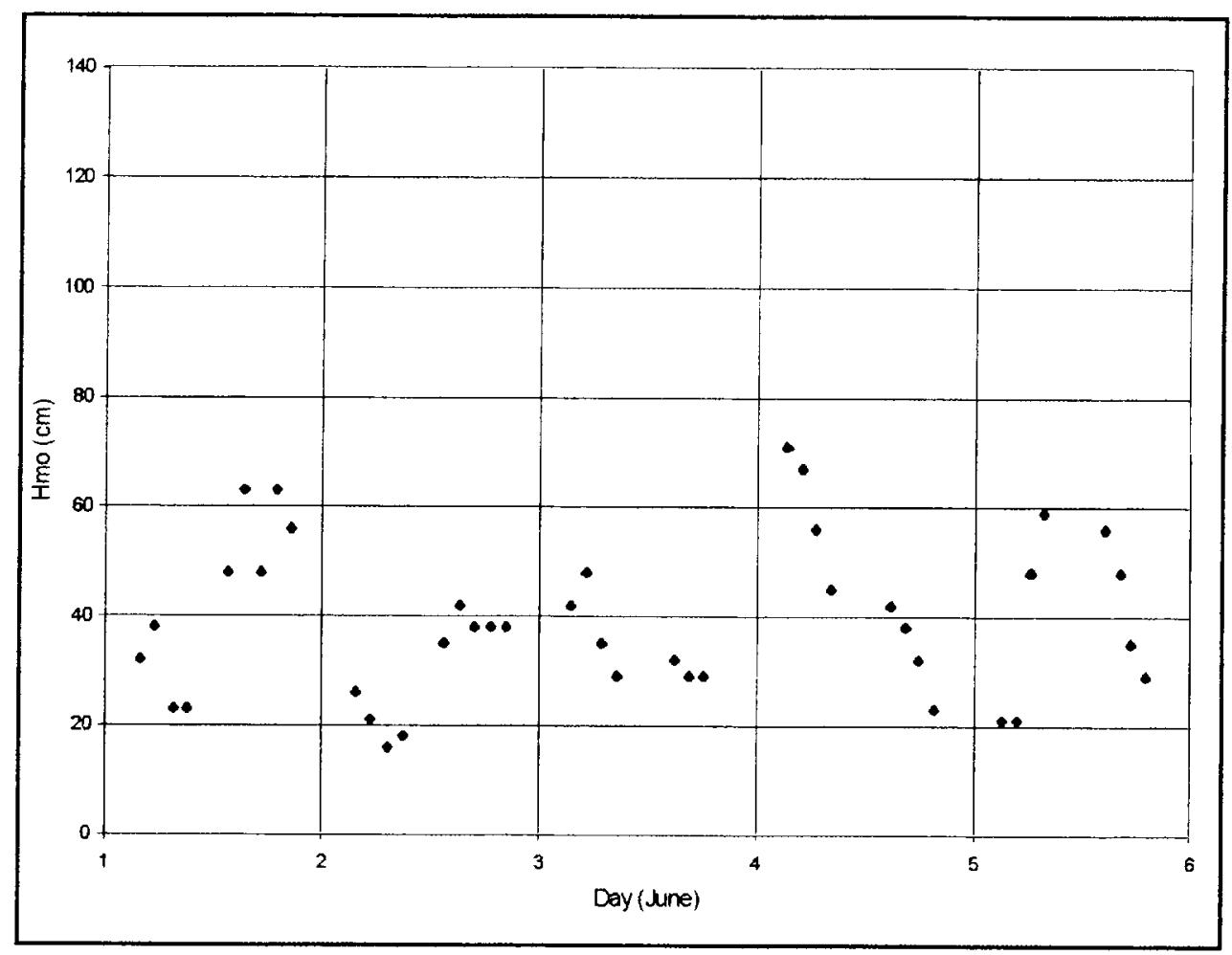

Figure 23. Measured $H_{\text {mo }}$ from 1 June through 5 June

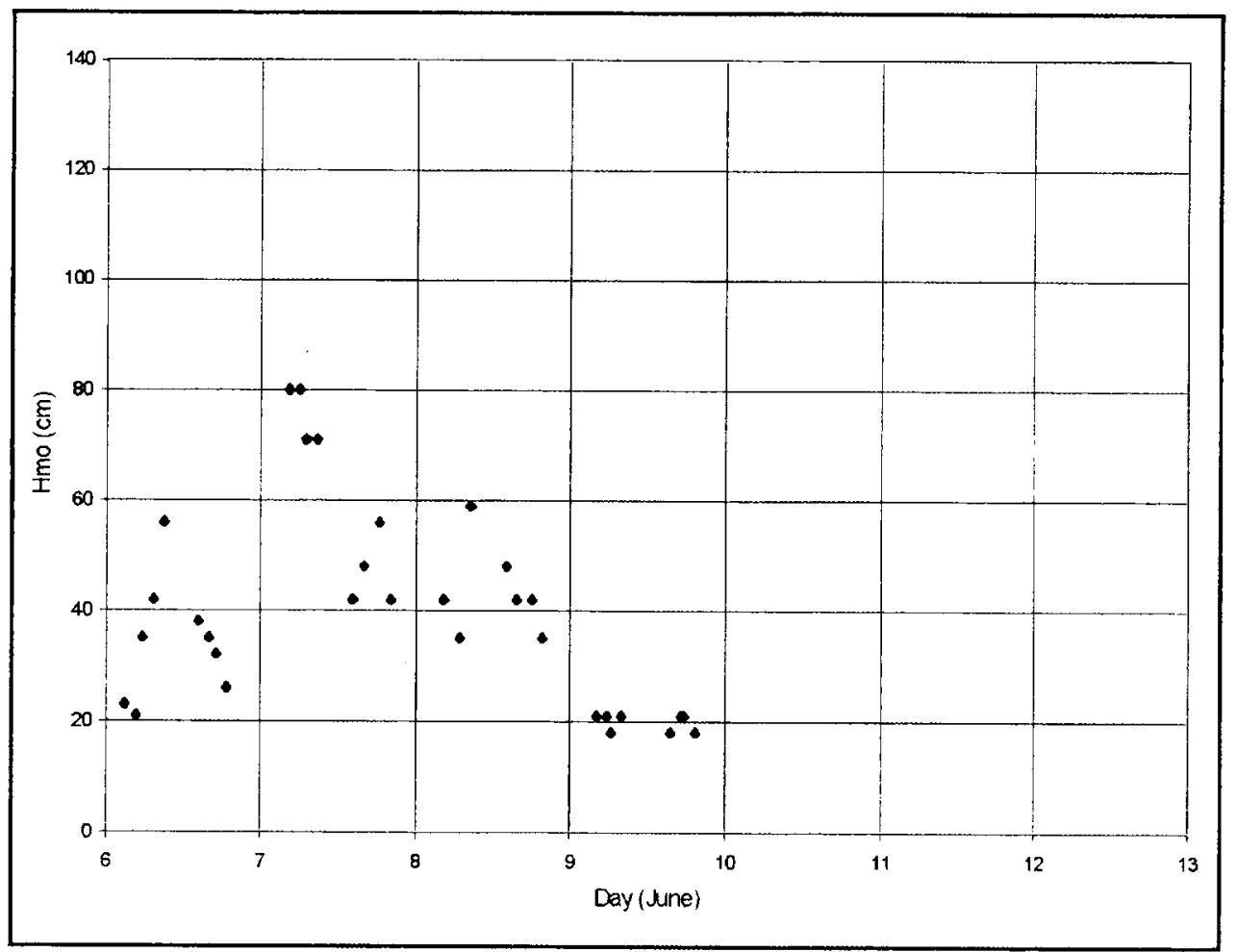

Figure 24. Measured $H_{\text {mo }}$ from 6 June through 9 June 


\section{ADCP Data}

Figures 25 and 26 show the near-surface current speed for data collected during the months of May and June, respectively. Tidal currents are strong in the area and the data show that current speeds exceeded $1.0 \mathrm{~m} / \mathrm{s}$ (1.9 knots) on several occasions.

Near-surface current direction, indicative of direction of flow, is shown in Figures 27 and 28 for data collected during the months of May and June. The figures indicate that current direction was generally east-west and strongly followed the diurnal tides. The long axis of the RRDF platform also was observed to be oriented either east or west throughout the experiment. The data and visual observations provided a strong indication that, as expected, tidal currents were the dominant factor in orientation of the RRDF. The effects of wave direction on platform orientation appeared to be minimal and only presented an appreciable influence on orientation during periods of slack tide. 


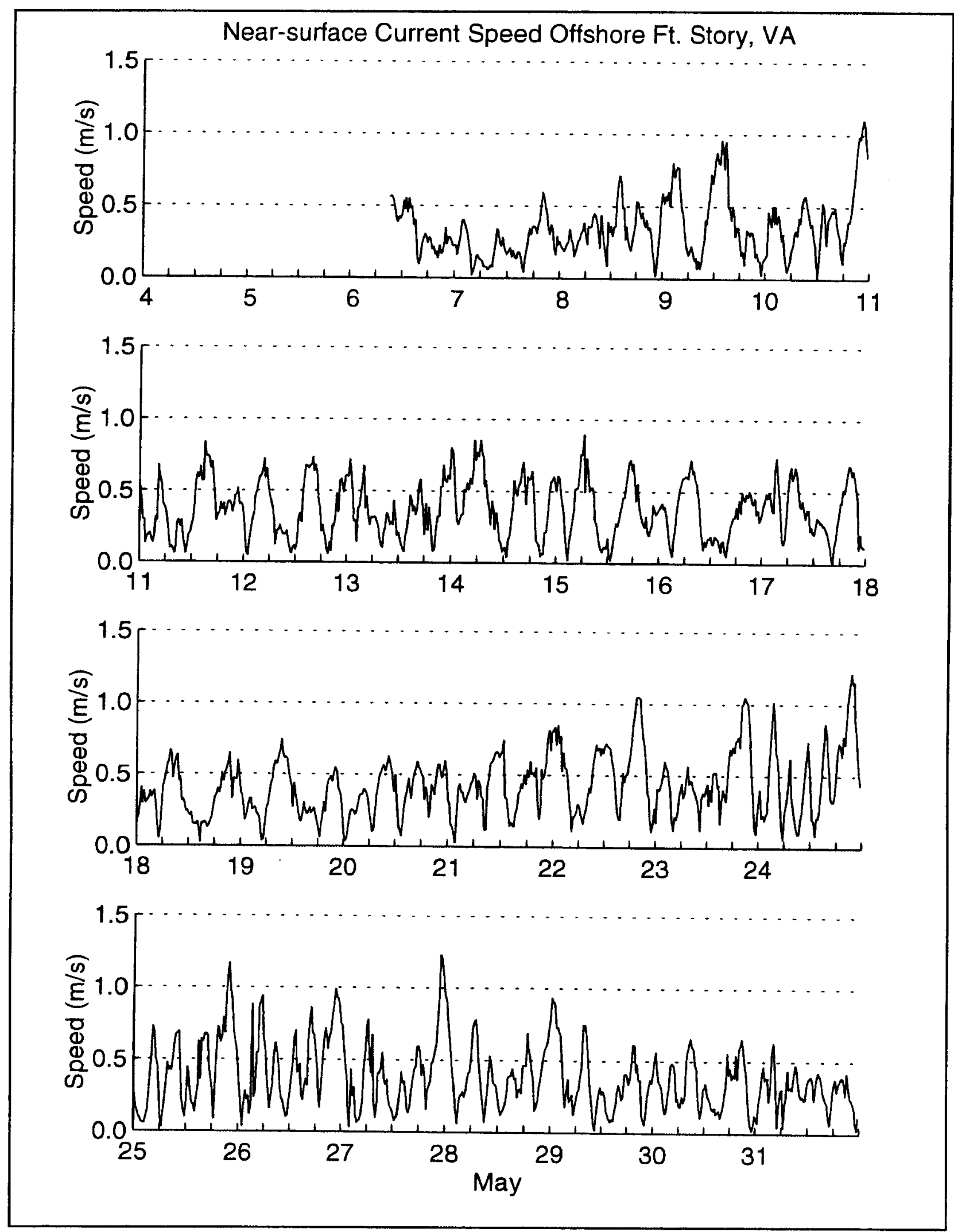

Figure 25. Near-surface current speed, May 1998 


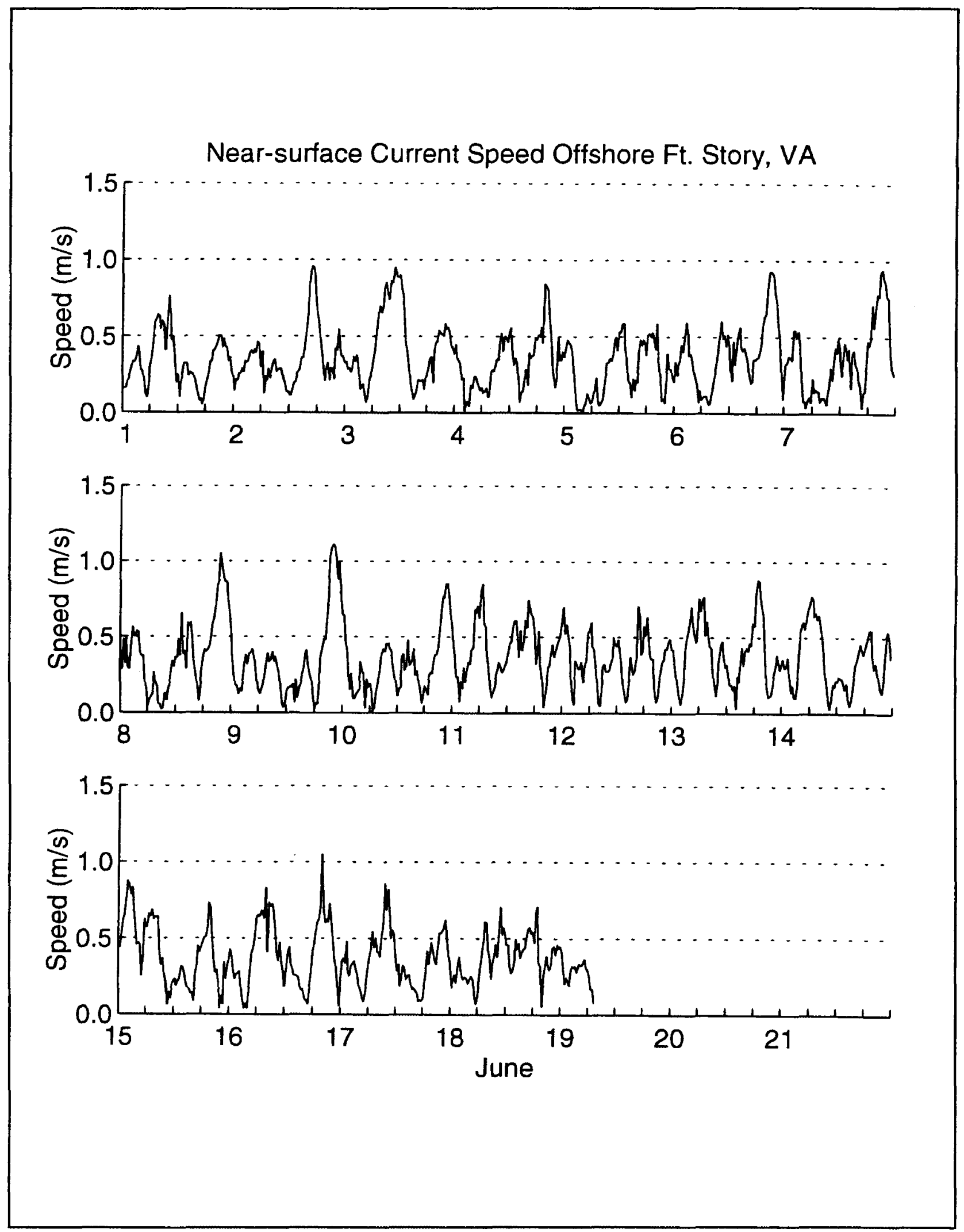

Figure 26. Near-surface current speed, June 1998 


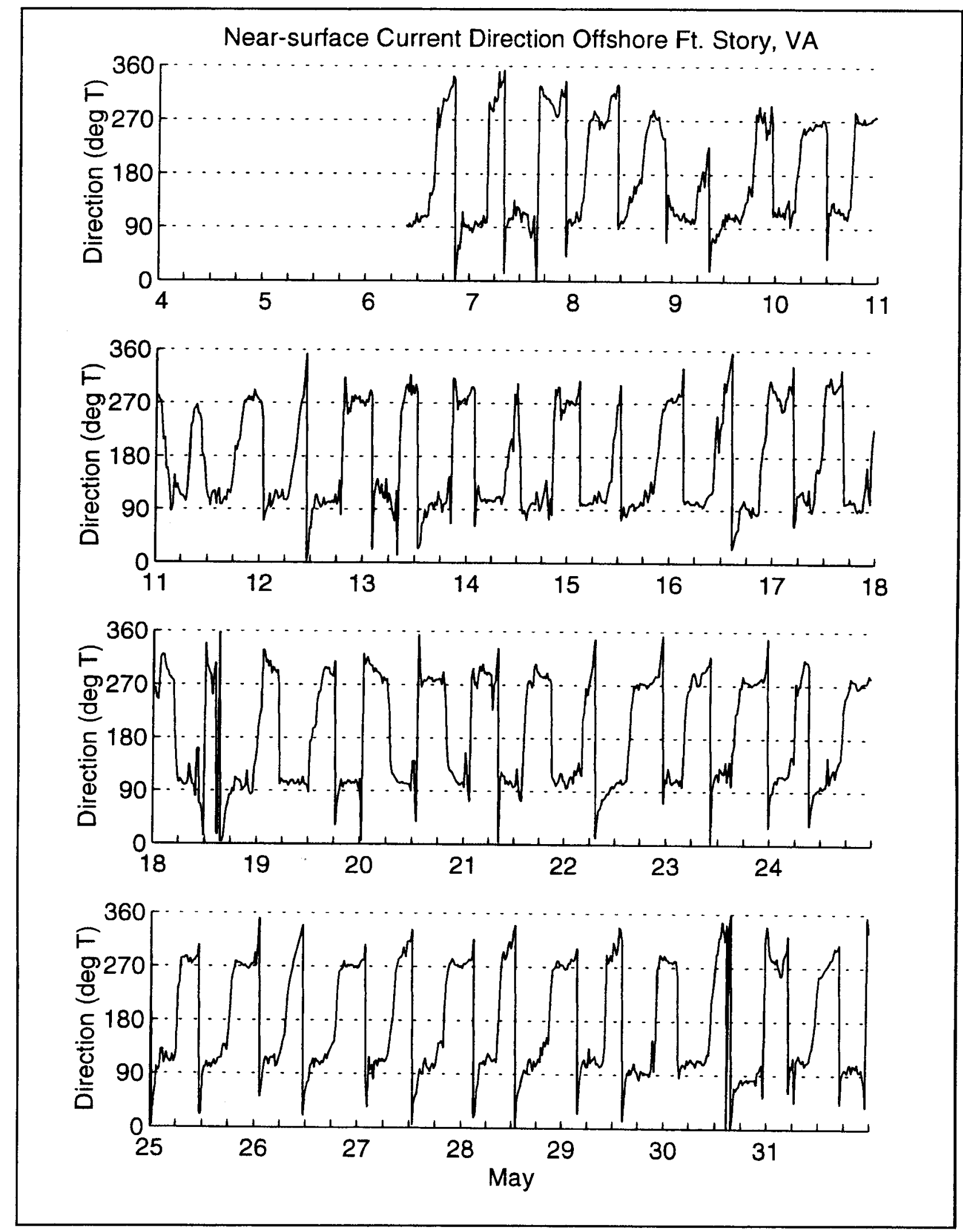

Figure 27. Near-surface current direction, May 1998 

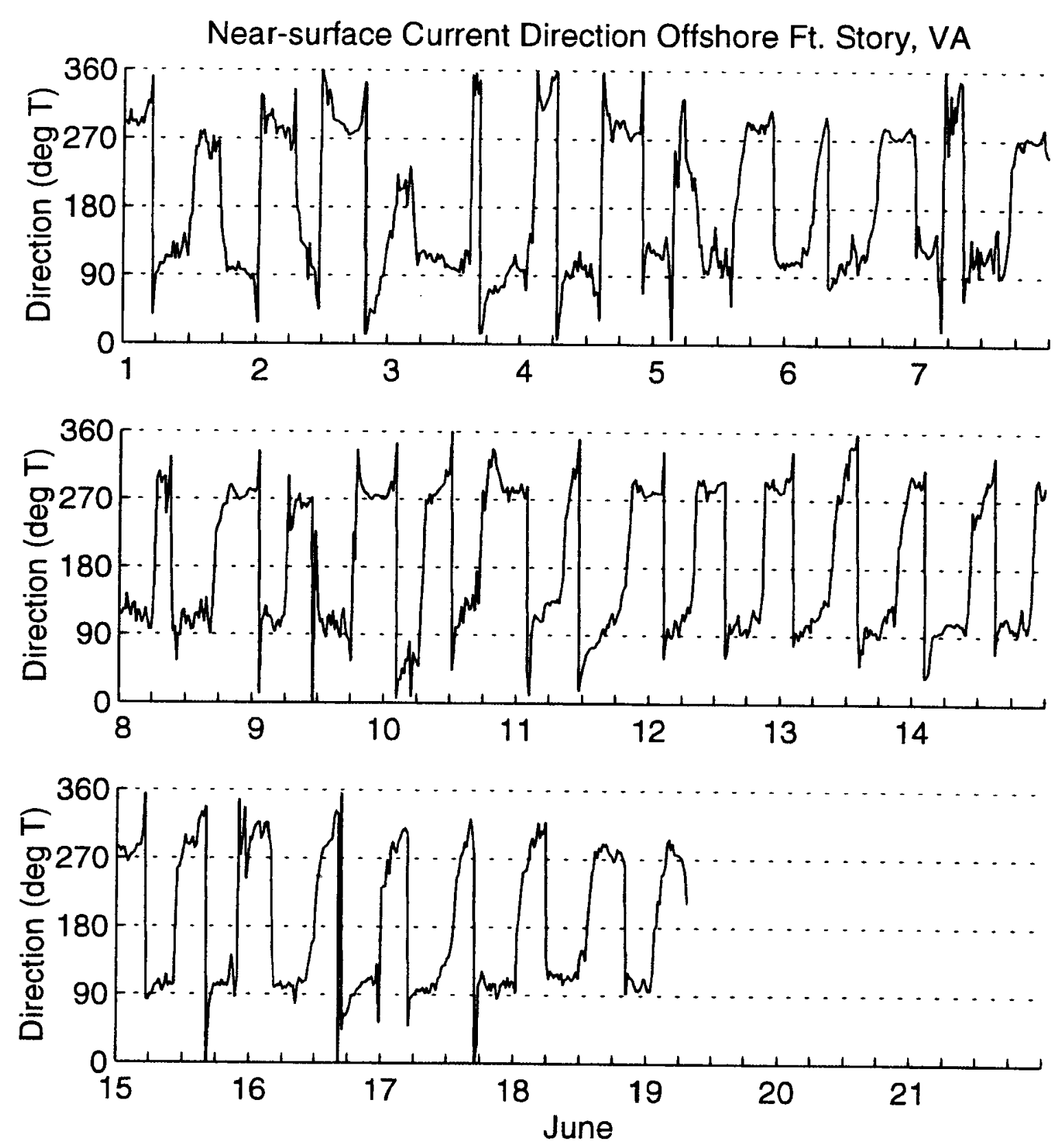

Figure 28. Near-surface current direction, June 1998 


\section{Summary}

A field experiment was conducted in Chesapeake Bay near Fort Story, Virginia, to determine the limitations and operational capabilities of an RRDF platform configured as shown in Figure 3. The goal of the experiment, which was conducted between 9 May and 9 June 1998, was to collect structural load data for conditions up to and including SS3 (significant wave heights up to $1.5 \mathrm{~m}(5 \mathrm{ft})$ ), and survivability of the platform for conditions up to and including SS5 (significant wave heights up to $3.7 \mathrm{~m}$ $(12 \mathrm{ft}))$.

Strain gauge and load cell data were collected from specially instrumented pins and structural members of the Modular Causeway Sections, which were used to configure the RRDF. Wave and current data were also obtained during the experiment to correlate with the strain gauge and load cell data.

Results of wave measurements showed that an upper SS3 condition was reached during the first week of data collection (13 May). Conditions were generally moderate for the remainder of the experiment; however, $\mathrm{SS} 2$ (significant wave heights in the range of 0.3 to $1.0 \mathrm{~m}$ (1 to $3 \mathrm{ft}$ )) was reached on nine other occasions following the storm of 13 May.

Measured currents exceeded $1.0 \mathrm{~m} / \mathrm{s}$ on numerous occasions. Generally, current direction was east-west and followed the diurnal cycle of the tide. From visual observations of the RRDF, it appeared that the platform orientation was driven by tide, and that the effects of wave direction on platform RRDF were minimal. 


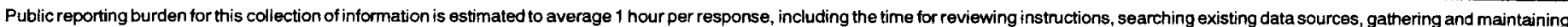

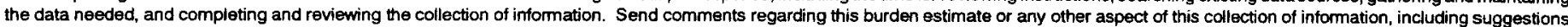

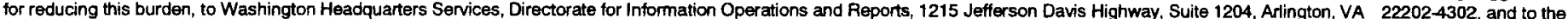
Office of Management and Budget, Paperwork Feduction Project (0704-0188), Washington, DC 20503.
1. AGENCY USE ONLY (Leave blank)
2. REPORT DATE
September 1998
3. REPORT TYPE AND DATES COVERED
Final report

4. TITLE AND SUBTITLE

RRDF Field Experiment Wave and Current Data Summary, Fort Story, Virginia

5. FUNDING NUMBERS

\section{AUTHOR(S)}

Ernest R. Smith, Jimmy E. Fowler

\section{PERFORMING ORGANIZATION NAME(S) AND ADDRESS(ES)}

U.S. Army Engineer Waterways Experiment Station 3909 Halls Ferry Road, Vicksburg, MS 39180-6199

8. PERFORMING ORGANIZATION REPORT NUMBER

Miscellaneous Paper CHL-98-8

10. SPONSORING/MONITORING AGENCY REPORT NUMBER

\section{SPONSORING/MONITORING AGENCY NAME(S) AND ADDRESS(ES)}

U.S. Army Tank and Automotive Command

Transportation Systems Management Office

6501 E. 11 Mile Rd., Warren, MI 48397-0002

\section{SUPPLEMENTARY NOTES}

Available from National Technical Information Service, 5285 Port Royal Road, Springfield, VA 22161.

\section{2a. DISTRIBUTION/AVAILABILITY STATEMENT}

Approved for public release; distribution is unlimited.

13. ABSTRACT (Maximum 200 words)

This report documents the wave and current data collected during a field experiment conducted in Chesapeake Bay near Fort Story, Virginia, to determine the limitations and operational capabilities of a roll-on/roll-off discharge facility (RRDF) platform. The goal of the overall experiment was to collect simultaneously structural load data and wave/current data for conditions up to and including sea state 3 (significant wave heights up to $5 \mathrm{ft}$ ), and survivability of the platform for conditions up to and including sea state 5 (significant wave heights up to $12 \mathrm{ft}$ ) if they occurred. Strain gauge and load cell data were collected by U.S. Army Aberdeen Test Center (ATC) from specially instrumented pins and structural members of the modular causeway sections that were used to configure the RRDF (these data were the responsibility of ATC and will be reported in a separate report). Wave and current data reported herein were obtained during the experiment to correlate with the strain gauge and load cell data.

\section{SUBJECT TERMS}

Current data

RRDF

Fort Story, Virginia

Roll-on/roll-off discharge facility
15. NUMBER OF PAGES

32

16. PRICE CODE

\section{SECURITY CLASSIFICATION OF REPORT \\ UNCLASSIFIED \\ 19. SECURITY CLASSIFICATION OF ABSTRACT}

